\title{
WHAT IS AN INTERNATIONAL POST-BELLIGERENT ADMINISTRATION?
}

\author{
Dr. Emmanuel Vianès \\ I. INTRODUCTION
}

Academic experts use many approximate terms to describe the whole framework of territorial administrations, relying on the resurgence of old concepts such as "international protectorate" or "colonial rule," associated with the idea of an international trusteeship (international authority). ${ }^{1}$ To refer to the subsequent practice, the terms of "benevolent autocracy" ${ }^{2}$ and "humanitarian occupation" 3 are used frivolously. For specialists looking for "heritage" of territorial administrations, the neo-colonial context could be explained by the fact that "[c]olonialism lasted long enough to destroy the preexisting social and political institutions, but not long enough to put anything solid and lasting in their place.” ${ }^{4}$ Some others even justify a form of neo-imperialism to maintain international order:

Those who imagine a world beyond empire imagine rightly, but they have not seen how prostrate societies actually are when nation-building fails, when civil war has torn them apart. Then and only then is there a case for temporary imperial rule, to provide the force and will necessary to bring order out of chaos. ${ }^{5}$

\footnotetext{
1 Peter Lyon, The Rise and Fall and Possible Revival of International Trusteeship, $31 \mathrm{~J}$. COMmonwEAlth \& COMP. POL., 96, 107 (U.K.) (“UN trusteeship would almost certainly be an improvement on the anarchical condition of the several quasi-states the world has now.”).

2 Simon Chesterman, Transitional Administration, State-Building and the United Nations, in MAKING STATES WORK: STATE FAILURE AND THE CRISIS OF GOVERNANCE 339 (Simon Chesterman, Michael Ignatieff \& Ramesh Thakur eds., 2005).

${ }^{3}$ Gregory H. Fox, Humanitarian OcCupation 3, 3-4 (2008) ("First their purpose has been to end human rights abuses, reform governmental institutions and restore peaceful coexistence among groups that had recently been engaged in vicious armed conflict. In this sense, they are humanitarian. The missions are social engineering projects that take international standards of human rights and governance as their blue prints. They may indeed be seen as the most far-reaching efforts at implementing those and other norms of social relations the international community has ever mounted. Second, the governing authority assumed by the international administrators is quite similar to the de facto authority of traditional belligerent occupiers. Both are outsiders to the territory they control, both assume ultimate legal authority and both are avowedly temporary. Just as occupiers under humanitarian law do not assume sovereign powers over the territory, the Security Council has consistently affirmed the sovereignty of the host state in creating humanitarian occupation missions. Humanitarian occupation, then, may be defined as the assumption of governing authority over a state or a portion thereof, by an international actor for the express purpose of creating a liberal democratic order.”).

${ }^{4}$ William Pfaff, A New Colonialism? Europe Must Go Back into Africa, 74 ForeIgn AfF. 1, Jan.Feb. 1995, at 2, 4.

${ }^{5}$ Michael IgnatiefF, EmPire Lite: NATION-BUilding in Bosnia, Kosovo, AND AFGHANistan 125 (2003).
} 
However, while territorial administrations in international relations are a big family, including foreign territorial administrations (colonial trusteeship, occupation, etc.) as well as hybrid territorial administrations, such as the mandates of the League of Nations (LoN) or the United Nations Trusteeship System, there is still another modern kind of territorial administration: the international post-belligerent administration (IPBA). This notion could be defined as a management structure in a post-belligerency situation, formally constituted and locally-based, operating within a singular territorial unit, whether a state or sub-state unit. ${ }^{6}$ This is the exercise of all state regulatory functions (pouvoirs régaliens), without the enjoyment of the territorial sovereign title, which emphasizes the temporary nature of this tool of territorial dispute settlement and/or of conflict resolution.

The use of the term "administration" refers to the management of la puissance publique (public power), ${ }^{7}$ whether in a plenary perspective, covering the executive, legislative, and judicial powers, or in a partial view where it is necessary to implement a program in a given territory. ${ }^{8}$ This practice is a political institution that performs many different functions: establishing and maintaining public order and internal security, providing humanitarian assistance after the conflict and supporting internally displaced persons (IDPs) and refugees, ensuring civil administration operations, creating local political institutions including a civil society and the election process, and reconstructing the socioeconomic aspects. In addition, IPBA established by a U.N. resolution under Chapter VII beyond the scope of peace enforcement and peacebuilding is based on several components: 1) the powers of administration, including regulatory powers are transferred to international actors (i.e. the United Nations); 2) the international actors are engaged in the exercise of authority and administration in the interest of and for the benefit of the local population; 3) a superposition of several (at least two) legal orders is recognized, namely the domestic legal order and an international legal order, bringing some changes in the applicable law and imposing obligations on the domestic and international actors; 4) the institutional architecture of the territory is indirectly internationalized by the creation of international or mixed executive and/or judicial institutions (i.e. convergence of international and domestic staff ); 5) such territory has an international legal entity which is (very) limited by the international actors in charge of the international relations of the territory, which means that the two parts of the sovereignty, the exercise of jurisdiction and the sovereign

\footnotetext{
${ }^{6}$ Ralph Wilde, International Territorial Administration: How Trusteeship and the Civilizing Mission Never Went Away 47, 4748 (2008).

7 Albane Geslin, Puissance publique et droit international, 5 TravauX DE L'Association FRANÇAISE POUR LA RECHERCHE EN DROIT ADMINISTRATIF 269 (2012) (Fr.).

8 ERIC DE BRABANDERE, POST-CONFLICT ADMINISTRATIONS IN INTERNATIONAL LAW: InTERnAtional TERritorial Administration, Transitional Authority AND Foreign OCCUPATION IN THEORY AND PRACTICE 2 (2009).
} 
property, are separated. ${ }^{9}$ The first condition to establish an IPBA is the restoration of public order and internal security in the territory to organize civil rule: the monopoly of legitimate violence must be restored as a basis of the authority of the native state. In this context, violence is not only understood in its "positive" meaning, that it is not only physical and visible, but also it may comprise negative aspects such as intimidation, fear of reprisal, persecution, or servitude. In situations of governance vacuum, the lack of police force and the disuse of the judicial system are the roots promoting the resurgence of anarchy in a society. In this case, IPBAs are responsible for the safety of the environment to a much higher degree compared to peace operations. ${ }^{10}$

Historically, IPBAs are not a new phenomenon. After the First World War, the international administration of the $\operatorname{Saar}^{11}$ or the international experimentation in the Leticia District ${ }^{12}$ in the early thirties under the responsibility of the LoN are good examples of the development of IPBAs in parallel to the creation of international institutions. Other examples can be considered as linked to the creation of IPBAs, such as the Free City of Danzig ${ }^{13}$ or the League's engagement in Memel. ${ }^{14}$ During the decolonization process, other IPBAs were established - at least partially—such as the United Nations Operation in the Congo (Opération des Nations Unies au Congo ONUC) $)^{15}$ or the Temporary Executive Authority of the United Nations in West New Guinea (UNTEA). ${ }^{16}$ And after the Cold War, due to the systematization of international governance, this form of conflict resolution and dispute settlement was renewed with the United Nations Transition Assistance Group in Namibia (UNTAG), ${ }^{17}$ the United Nations Transitional

\footnotetext{
${ }^{9}$ Carsten Stahn, The United Nations Transitional Administrations in Kosovo and East Timor: A First Analysis, 5 Max PlanCK Y.B. United NATIONs L. 105, 181 (2001) (Ger.).

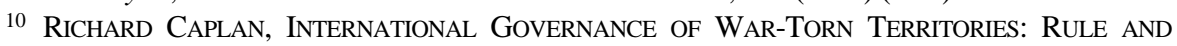
RECONSTRUCTION 45 (2005).

11 Frank M. Russell, The International Government of the SAar 134 (1926). See also Sarah Wambaugh, The SaAr Plebiscite: With a Collection of OfFicial Documents 16-36 (1940); FrANCiS P. WALTERS, A History OF THE LEAGUE OF NATIONS 586-89 (1952).

12 L. H. Woolsey, Editorial Comment, The Leticia Dispute between Colombia and Peru, 29 AM. J. INT’L L. 525 (1933).

13 Julien Makowski, La situation juridique du territoire de la ville libre de Dantzig, 30 REVUE GÉNÉRALE DE DROIT INTERNATIONAL PUBLIC 56 (1923) (Fr.).

${ }^{14}$ Convention Concerning the Territory of Memel, May 8, 1924, 1924 L.N.T.S. 87.

${ }^{15}$ William J. Durch, The UN Operation in the Congo: 1960-1964, in The Evolution of UN PeaceKeEPing: Case Studies and Comparative Analysis 315, 316 (William J. Durch ed., 1993). ${ }^{16}$ Daniel Gruss, UNTEA and West New Guinea, 9 MAX PlancK Y.B. United NATIONs L. 97 (2005) (Ger.).

${ }^{17}$ Raymond Goy, L'indépendance de la Namibie, 37 AnNUAIRE FranÇAIS DE DroIT INT’L 387 (1991) (Fr.).
} 
Authority in Cambodia (UNTAC), ${ }^{18}$ and especially the United Nations Transitional Administration in Eastern Slavonia (UNTAES), ${ }^{19}$ and most recently and fundamentally with the Office of the High Representative (OHR) in Bosnia and Herzegovina (BiH), the United Nations Interim Administration Mission in Kosovo (UNMIK), as well as the United Nations Transitional Administration in East Timor (UNTAET), although there are other partial experiences and non-implemented projects. ${ }^{20}$

Faced with this terminological and historical complexity, it is necessary to outline what an IPBA is. This article defines the structures and purposes of IPBAs and it concludes by arguing for changes to the current international legal framework establishing IPBAs to improve their functionality regarding the contemporary subsequent practice. To fully understand this concept, it is firstly necessary to define this notion by its own characteristics. Secondly, the taxonomic criteria should be analyzed, and thirdly, the contemporary subsequent practice should be revealed in the light of the evolution of the international legal order in general, and in the light of the changes in peace operations doctrine in particular.

\section{NORMATIVE CONCEPTUAL CHARACTERISTICS}

It is difficult to separate definitional and taxonomic attributes, as some markers overlap, contributing both to the definition and classification. To grasp the concept of IPBA, it is necessary to differentiate the strict criteria from those which would be more flexible.

\footnotetext{
${ }^{18}$ Paul Isoart, L'Autorité provisoire des Nations Unies au Cambodge, 39 ANNUAIRE FRANÇAIS DE DroIT INT'L 157 (1993) (Fr.). See also Lucy Keller, UNTAC in Cambodia - from Occupation, Civil War and Genocide to Peace, 9 MAX PLANCK Y.B. UnITED NATIONS L. 127 (2005) (Ger.).

19 Johan Schoups, Peacekeeping and Transitional Administration in Eastern Slavonia, in PeAcebuilding: A Field Guide 389 (Luc Reychler \& Thania Paffenholz eds., 2001). See also Derek Boothby, The Political Challenges of Administering Eastern Slavonia, 10 GLOBAL GOVERNANCE 37, 41 (2004).

${ }^{20}$ Other cases, such as Vilnius, High Silesia, Fiume (project non-implemented), Jerusalem (project non-implemented), the Free Territory of Trieste (project non-implemented), the U.N. Council for Namibia or the U.N. Mission for the Referendum in Western Sahara (MINURSO - project not really implemented), as well as the U.N. Operation In Somalia II (UNOSOM II). WALTERS, supra note 11, at 406-08, 447-48. See also S.C. Res. 16, U.N. Doc. S/RES/16 (Jan. 10, 1947); JAMES R. Crawford, The Creation of States in International LaW 534-35 (2006); JoËLle Le MorZELLEC, LA QUESTION DE JÉRUSALEM DEVANT L'ORGANISATION DES NATIONS UNIES (1976);

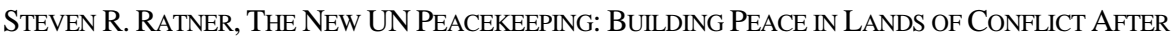
THE COLD WAR 95-120 (1995); Jarat Chopra, Breaking the Stalemate in Western Sahara, 1 INT'L PeaceKeEPING, 303, 307 (1994) (U.K.); Laurent Lucchini, La Namibie. Une construction des Nations unies, 15 ANNUAIRE FranÇAIs DE Droit InT’L 355, 359 (1969) (Fr.); Christiane E. Philipp, Somalia - A Very Special Case, 9 Max PlancK Y.B. United NATIONS L. 518 (2005) (Ger.).
} 


\section{A. Strict Criteria}

The strict criteria are those which are stable and rigid. Consequently, this means that they could not be changed to undermine what an IPBA is.

\section{International Exogenous Actor Versus Local Endogenous Actor}

First, it is important to focus on the identity of the actor, which refers to two kinds of actors: on the one hand, the international exogenous actor, and on the other hand, the endogenous actor, namely the local population and its elites. The link between the international actor and the activity of the administration is the "essence" of the relationship created by the exogenous actor. The functional international identity of the actor and the spatial identity of the territory should be connected: on the one hand the arrangements are local, insofar as they are based in a territory and they are determined on behalf of the population; on the other hand, the identity of the actor is international and functional, because it concerns international civil servants working for an international organization, which fulfills administrative functions in the field. The spatial identity of the international actor-although differentiated from the local identity of the population and territorial unit-is still shaped by the local society, because it influences the decision-making process developed by international actors. ${ }^{21}$ The IPBA is a distinctive activity because a dichotomy between the IPBA identity and the spatial identity of the territorial unit administered (population included) is acknowledged. International officials are staff seconded by Member States and owe their appointment to the selection procedures of international organizations. ${ }^{22}$ These foreign government officials have political, administrative, or judiciary positions within a territorial unit that is not theirs and benefit from special status due to bodies created by an international organization. At the outset of the mission, these bodies are in the hands of international civil servants, but as the mission goes along, these structures evolve to a local or domestic framework (sub-state territorial unit or state). ${ }^{23}$ Therefore, international bodies take a hybrid form due to local interference within them, especially for electoral commissions, mixed international tribunals, truth and reconciliation Commissions, as well as other bodies dealing with human

\footnotetext{
${ }^{21}$ WILDE, supra note 6, at 26-30.

22 JosÉ E. AlVAREZ, INTERNATIONAL ORGANIZATIONS AS LAW-MAKERS 44 (2005) (“[I]nterests flow from a constructed identity and the identities of all actors in international relations fluctuate either through different association with others (as through participation in an IO) or through changing self-perceptions (which can also be influenced through the normative activity of IOs).”).

${ }^{23}$ See Regulation No. 64 on Assignment of International Judges/Prosecutors and/or Change of Venue, UNMIK/REG/2000/64 (Dec. 15, 2000). See also Regulation No. 2000/1 on the Establishment of the Central Fiscal Authority of East Timor, UNTAET/REG/2000/1 (Jan. 14, 2000).
} 
rights or administrative structures. It seems that the international actor-the LoN, the United Nations, or another international ad hoc form-is the best guarantee of objective conditions when it comes to meeting the challenges of erosion of the social contract, in contrast to unilateral action. ${ }^{24}$ In this case, the international actor is responsible to the states it represents (external accountability) and is accountable to the local population (internal accountability). In theory, this would be its dual accountability. ${ }^{25}$

\section{Territory Status}

Secondly, the status of the territory should be investigated on the grounds that the notion of IPBA maintains close ties with sovereignty. Sovereignty has a double meaning: on the one hand, sovereignty means the rights of the owner - the sovereign - and therefore the state in a given territorial unit; on the other hand, sovereignty emphasizes the jurisdiction (in the sense of power) and control over a territory. This dualism generally leads to the union of the territorial unit (spatial) and the legal personality of the state, despite the original difference between land ownership and administration (control and jurisdiction). ${ }^{26}$

For IPBAs, it happened that this concept was likened to that of "internationalized territory," considering that property rights derive from the right of administration, making an illusory link between the administration exercised by international actors in post-belligerency and sovereignty. In concreto, internationalized territory is a territorial unit that is not an integral part of a state where sovereignty is partially or fully granted and exercised by a non-local actor. The condition par excellence of territory internationalization is its unlimited temporal nature, ${ }^{27}$ which contrasts with the delimited duration of an IPBA. In this sense, the idea of perpetual sovereignty of internationalized territories exists, but it cannot be applied to IPBAs, insofar as it is essential to take into account the nature of the exercised activity. On the one hand, the establishment of an IPBA never relies on the territorial sovereignty title, as the international actor is merely a temporary

${ }^{24}$ Fox, supra note 3, at 118-21.

25 Yves Daudet, L'action des Nations Unies en matière d'administration territoriale, 6 CuRsos EUROMEDITERRANEOS BANCAJA DE DERECHO INTERNACIONAL 459, 507-09 (2002) (Spain).

${ }^{26}$ JEAN COMBACAU \& SERGE SUR, DROIT INTERNATIONAL PUBLIC 426, 426-28 (2010).

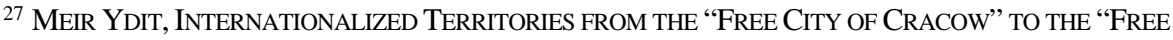
CITY OF BERLIN" 11, 20-21, 320 (1961) (This thought focuses on the fact that the sovereign title is permanently granted to a non-local public actor, as a representative of the international society as well as of the internationalized territory. This theory seeks above all sustainable solutions to the territorial disputes with an internationalizing process: "populated areas established for an unlimited duration as special State entities in which supreme sovereignty is vested in (or de facto exercised by) a group of States or in the organized international community" and "[t]he local element in these territories is restricted in its sovereign powers by the provision of an International Statute (Charter, Constitution, etc.) imposed upon it by the Powers holding supreme sovereignty over the territory.”). 
administrator, but in no case the territorial sovereign; and the other hand, although the establishment of an IPBA is legal and legitimate according to the terms of the involved international organization's founding covenant (or charter), the exercise of administrative prerogatives over a territorial unit is not enough to enjoy the sovereign title. The international actor provides the right to administer a territory without prejudice to its status. It is likely the same distinction between the concept of "government" and that of "state": the government does not have a legal personality, but is an agent acting on behalf of a legal entity, the state. For this reason, it seems more sensible to refer to a "framed" or "suspended" sovereignty, because the international actor responsible for an IPBA has sovereign prerogatives (prérogatives régaliennes) but does not have the title of sovereignty. ${ }^{28}$ When an IPBA is established, the legal status - the title of sovereignty - of a state or of a territorial unit is not altered, although the IPBA enjoys the exercise of administrative control, i.e. the international actor becomes an agent of the territorial sovereign respecting its sovereign title, while performing its duties. ${ }^{29}$ However, it is more complicated when it is neither a state nor a territorial state unit. The status of these non-state territories administered by an international actor does not lead to the development of international territorial sovereignty, ${ }^{30}$ because the international actor (the LoN or the United Nations) does not claim the title of sovereignty, and because this kind of territory-based on the principle of self-determination ${ }^{31}$-may have a legal personality at the international level in accordance with the right to self-

28 Alexandros Yannis, The Concept of Suspended Sovereignty in International Law and its Implications in International Politics, 13 EUR. J. INT'L L. 1037 (2002) (U.K.). See also Robert O. Keohane, Political Authority after Intervention: Gradations in Sovereignty, in HuMANITARIAN INTERVENTION: ETHICAL, LEGAL AND POLITICAL DilemMAs 275, 293-297 (J. L Holzgrefe. \& Robert O. Keohane eds., 2003); DANIEL Sven SMYREK, INTERNATIONALLY ADMINISTERED TERRITORIES INTERNATIONAL PROTECTORATES? AN ANALYSIS OF SOVEREIGNTY OVER INTERNATIONALLY AdMinistered TERRITORIES With SPECIAL REFERENCE to THE LEGAL STATUS OF POST-WAR Kosovo 24, $24-27$ (2006); Christian Tomuschat, Yugoslavia's Damaged Sovereignty over the Province of Kosovo, in State, SOvereignty, AND InTERnATIONAL GOVERnANCE 323, 323-26 (Gerard Kreijen ed., 2002); Michael P. Scharf, Earned Sovereignty: Juridical Underpinnings, 31 DenV. J. InT'L L. \& Pol'y 373 (2003); Paul R. Williams, Earned Sovereignty: The Road to Resolving the Conflict over Kosovo's Final Status, 31 DENV. J. INT’L L. AND POL’y 387 (2003); Paul R. Williams \& Francesca Jannotti Pecci, Earned Sovereignty: Bridging the Gap between Sovereignty and Self-Determination, 40 STAN. J. INT'L L. 1 (2004).

${ }^{29}$ WILDE, supra note 6, at 147-51.

${ }^{30}$ Jarat Chopra, The UN's Kingdom of East Timor, 42 SuRviVAL (U.K.), Autumn 2000, at 27.

${ }^{31}$ U.N. Charter, art. 1, ๆ 2 ("To develop friendly relations among nations based on respect for the principle of equal rights and self-determination of peoples, and to take other appropriate measures to strengthen universal peace.”); id. art. 22 ("With a view to the creation of conditions of stability and well-being which are necessary for peaceful and friendly relations among nations based on respect for the principle of equal rights and self-determination of peoples, the United Nations shall promote.”). 
determination. ${ }^{32}$ In this way, a population with the right to external selfdetermination is often designated by the term "people" and its territory is identified as a "unit of self-determination": this title is given to U.N. trusteeships as well as non-autonomous territories (covering also the colonial territories), as long as these territories are not independent states, to establish an ad hoc mechanism to resolve specific territorial disputes. According to Resolution 2625 of the U.N. General Assembly (UNGA), a "unit of selfdetermination" is a separate legal entity. This type of territory-noninternationalized non-state units-has a separate legal personality resulting from its right to self-determination. The international actor acts as an agent of a legal sui generis entity and the territorial unit of self-determination does not benefit from the sovereign title in accordance with the principle of selfdetermination. It implies that such territorial units cannot be defined as a terra nullius and an international actor (or any other legal entity) may not enjoy the title of sovereignty over these territories only by exercising an administrative control. ${ }^{33}$ In fine, whether it is about a state, a state unit, or a non-autonomous territory, the IPBA does not establish an international territorial sovereignty. The international actor within the IPBA has plenary or partial administrative and political powers without enjoying the title of sovereignty over the territory. Therefore, the sovereignty of the territory is "suspended" or "framed" to the extent that the international actor performs the functions of the public authority. This type of territory has a very limited international personality, as the international actor/authority should be able to manage international relations of these territories on behalf of the peoples.

\section{Post-Belligerency}

Thirdly, the post-belligerency nature of an IPBA should be considered as a fundamental criterion, because international relations history teaches that wars traditionally end with negative peace, usually qualified as unjust. The victor determines everything without consideration and the defeated party loses everything. An IPBA plays an important role in building peace because it is a tool for developing an inclusive approach to conflict resolution and peacebuilding. It is a cornerstone of the modern practice of peacemaking by turning territories and peoples in a situation of anarchy toward the building of a society ordered by law, in which social peace reigns, as well as by reintegrating states excluded from international society. The vast majority of

\footnotetext{
32 The principle of self-determination has two distinct elements: the external characteristic entitles a people to choose the external status of its territory (international), either by forming a free association with another state, or by becoming an independent state, while that internal selfdetermination is the right of peoples within states. G.A. Res. 1541 (XV), princs. II, VI-IX, U.N. GAOR, 15th Sess., U.N Doc. A/RES/1541 (Dec. 15, 1960); G.A. Res. 2625 (XXV), U.N. Doc. A/RES/25/2625 (Oct. 24, 1970).

33 DE BRABANDERE, supra note 8, at 70-88.
} 
IPBA experiments are closely related to different forms of conflict, whether responses to international conflicts (such as the experiences in the Saar, Leticia, former Yugoslavia, etc.) or to intra-state conflicts (such as the cases in Congo, Cambodia, Eastern Slavonia, Kosovo, etc.). Sometimes an IPBA unfolds in situations where civil war coexists with international armed conflict, especially in the case of $\mathrm{BiH}$. It is therefore necessary either to manage as far as possible the consequences of a conflict or to put an end to violent conflict. ${ }^{34}$ Since the end of the Cold War, the U.N. Security Council (UNSC) provides the legal basis for this type of mission through resolutions under Chapter VII of the Charter to respond to a threat against international peace and security. ${ }^{35}$ Contemporary IPBAs are a direct international response to territories that experience a more or less violent armed conflict. In this way, IPBAs are often imposed after an intra-state conflict, which is a reflection of disintegration of the state structures, meaning that this abstract notion is set up after the restoration of negative peace, after an agreement between the belligerents, after a U.N. peace operation, or after a military intervention by international society, to build positive peace. So, IPBAs are established after a conflict and are intended to manage the consequences of the latter. ${ }^{36}$ A priori, it appears that the designation of such international administrations under the label "post-belligerent" or "post-conflict" is the rule as evidenced by the different experiments.

Nevertheless, there is an exception to the rule; it is the West New Guinea case, where the establishment of the international authority is preventive and not curative to resolve a territorial dispute. In this case, an IPBA was established by international society to avoid the exacerbation of tensions relating to the transfer of the territory from the Netherlands to Indonesia, which would probably have resulted in a conflict either internal or international. Ultimately, whether intra-state conflicts, international conflicts, or hybrid wars, history teaches that reference to post-belligerency is an essential criterion to resolve a territorial dispute or face governance issues. IPBAs are a direct response to the anarchy that results from physical, political, societal, legal, internal, or external disorder. Establishing an IPBA reflects a causal relationship with international peace and security.

\section{B. Flexible Criteria}

Having highlighted the strict features of an IPBA, some flexible

\footnotetext{
${ }^{34}$ Michael J. Matheson, United Nations Governance of Postconflict Societies, 95 AM. J. INT’L L. 76 (2001).

${ }^{35}$ U.N. Charter, art. 39. ("The Security Council shall determine the existence of any threat to the peace, breach of the peace, or act of aggression and shall make recommendations, or decide what measures shall be taken in accordance with Articles 41 and 42, to maintain or restore international peace and security.”).

${ }^{36}$ CAPLAN, supra note 10 , at 2, 5-6, 45-67.
} 
elements can refine the sense of the notion. By flexible characteristics, it is necessary to understand those that offer more possibilities and are not fixed, which allows the introduction of a discussion for the next step.

\section{Legality and Legitimacy}

First of all the question of legality and legitimacy is the most important flexible criterion to understand the normative concept of IPBA. Indeed, the exercise of public authority by an international actor in a territorial unit raises questions about its legality and legitimacy. ${ }^{37}$ It is obvious that an IPBA, which is le cas par excellence of the exercise of territorial jurisdiction without the sovereign title by a non-state actor, can cause problems related to the legal framework of its establishment and the legitimacy of such an undertaking. IPBAs are not a formal practice, and they are not institutionalized, as U.N. trusteeships may have been. The U.N. Charter makes no reference to this concept and there is no U.N. body addressing IPBA issues. Although, during the U.N. Charter drafting process, the proposal of the Norwegian delegation suggested a U.N. role in the administration of territory in the event of a threat against international peace and security, ${ }^{38}$ the only explicit prospect-so that the United Nations provides the executive ability-happens to be the U.N. Trusteeship System, which is never invoked when IPBAs are created ${ }^{39}$ because a member state cannot be placed under the U.N. Trusteeships System. ${ }^{40}$ This is the reason why it is inconceivable to place territories or states under the U.N. Trusteeships System against their will. Thus, the implementation of an IPBA operates always on an ad hoc basis. An IPBA does not draw its legitimacy from an old standard of "sacred trust of civilization," but it is related to normative developments in international law. It is no longer a moral responsibility but a legal responsibility relating to international security and peace: the development of several concepts such as

37 David Hartland, Legitimacy and Effectiveness in International Administration, 10 GLOBAL GOVERNANCE, Jan-Mar. 2004, at 15-19.

${ }^{38}$ Commission III, Committee 3, at 353-55, UNCIO, Vol. XII, U.N. Doc. 539 III/3/24 (May 23, 1945).

${ }^{39}$ U.N. Charter, art. 81. ("The trusteeship agreement shall in each case include the terms under which the trust territory will be administered and designate the authority which will exercise the administration of the trust territory. Such authority, hereinafter called the administering authority, may be one or more states or the Organization itself.”).

40 U.N. Charter, arts. 77, 78. ("1. The trusteeship system shall apply to such territories in the following categories as may be placed thereunder by means of trusteeship agreements: a. territories now held under mandate; $b$. territories which may be detached from enemy states as a result of the Second World War; and c. territories voluntarily placed under the system by states responsible for their administration. 2. It will be a matter for subsequent agreement as to which territories in the foregoing categories will be brought under the trusteeship system and upon what terms. ... The trusteeship system shall not apply to territories which have become Members of the United Nations, relationship among which shall be based on respect for the principle of sovereign equality.”). 
"failed state," 41 “[r]esponsibility to protect," 42 or intervention d'humanité ("humanity intervention") ${ }^{43}$ paves the way towards the involvement of international organizations in matters relating to the establishment of IPBAs. Historically, the establishment of an IPBA is based on the consent of the host state, on a treaty, and/or on an international mandate (UNSC resolutions). Since the nineties, the UNSC has fully used its powers under Chapter VII to establish IPBAs. ${ }^{44}$ At the beginning, the establishment of an IPBA may be the product of an agreement between the international actor and the territorial sovereign-like ONUC, UNTEA, UNTAC, or UNTAES. The delegation of authority is therefore granted. The international actor must weave again the bonds of the social contract between rulers and citizens; that is why it substitutes the local rulers by replacing them, echoing the volunteer dimension which is at the heart of the raison d'être of international organizations. However, it can also be derived from a simple effectiveness, for example in the event of a total vacuum of governance or violent conflict that has destroyed any form of state organization, such as the experience in Somalia with UNOSOM II. After 1945, the legality is compounded by the international mandate and the role of the U.N. Secretary General (UNSG). From the start, in accordance with Article 2 of the UN Charter, the respect for national competence is essential, that is why the consent of the host state is logically required. ${ }^{45}$ However, there are several alternatives: the first one is the establishment of an IPBA when the sovereign authority has collapsed; the second one, lackluster, is identifiable with coercive consent, inducing strong international pressure and the use of military force. Even if it is still banned by Article 52 of the Vienna Convention, it empirically appears to be true. ${ }^{46}$ And the third one is related to UNSC Resolutions: Chapter VII of the U.N. Charter is considered as an obligation that surpasses the absence of state consent, which means that the UNSC has binding powers to interfere greater than the will of the state concerned. So, since the drafting of the Charter,

\footnotetext{
${ }^{41}$ Gerald B. Helman \& Steven R. Ratner, Saving Failed States, 89 ForEIGN POL’Y, Winter 19921993, at 3.

42 Carsten Stahn, Responsibility to Protect: Political Rhetoric or Emerging Legal Norm? 101 AM. J. INT'L L. 100 (2007).

43 Antoine Rougier, La Théorie de l'intervention d'humanité, 17 REVUE GÉNÉRALE DE DROIT InTERNATIONAL PuBlic 486 (1910) (Fr.).

${ }^{44}$ ERIKA De Wet, The Chapter VII Powers of THE United NATIONS SeCurity CounCIL 311-37, 369-86 (2004).

${ }^{45}$ U.N. Charter, art. 2, para. 7. ("Nothing contained in the present Charter shall authorize the United Nations to intervene in matters which are essentially within the domestic jurisdiction of any state or shall require the Members to submit such matters to settlement under the present Charter; but this principle shall not prejudice the application of enforcement measures under Chapter VII.”). ${ }^{46}$ Vienna Convention on the Law of Treaties art. 52, May 23, 1969, 1155 U.N.T.S. 344 (entered into force Jan. 27, 1980) ("Coercion of a state by the threat or use of force: a treaty is void if its conclusion has been procured by the threat or use of force in violation of the principles of international law embodied in the Charter of the United Nations.”).
} 
consent is not legally a necessity, although it provides a superior legitimacy. ${ }^{47}$ Another rare alternative for an IPBA legal basis is an UNGA Resolution, as evidenced by the creation of UNTEA. ${ }^{48}$ Ultimately, the range of legal options relating to the creation of an IPBA since the establishment of the United Nations depends in essence on the role of the executor, i.e. the UNSG. The latter is intended to implement the decisions taken in the field of peacekeeping by providing regulatory powers severely limited and supervised by Chapter XV of the U.N. Charter. It gives to the highest official of the Organization two major responsibilities in maintaining international peace and security: the power to perform the functions conferred on him by other U.N. bodies and the authority to draw the UNSC's attention to any matter which constitutes in his view a threat to peace and security. ${ }^{49}$ In institutional practice, the UNSG is rather responsible for managing projects, from planning to implementation. For contemporary IPBAs, the UNSG plays a major role in the negotiations on the IPBA structure and on its institutional implementation. ${ }^{50}$

Moreover, the legal basis (i.e. consent and mandate) contributes to creating legitimacy for the establishment of such institutions. In addition, the IPBA policy is perceived as legitimate to the extent that it tends to establish standards relating to human rights internationally recognized and universally applicable. This universalism refers directly to the general public interest, the symbol of an international society that aims to establish a global community for perpetual peace. Furthermore, the implantation of democratic governance in a territorial unit, onto which is grafted an IPBA, can also help to strengthen the legitimacy of the mission by giving "power to the people.” Finally, this legitimacy is also reinforced by the actor's international identity which has the prerogatives over the territory: the international organization, by being impartial and neutral, is better able to defend the local population's interests and the general interests in the international system than a special state actor. ${ }^{51}$ Today, the central issue is not knowing what the IPBA legitimacy or legality is, but rather what the legal limit facing the IPBA legitimacy and authority is. ${ }^{52}$ In this regard, the U.N. Charter is explicit: the administration must act in the interests of the local population (political and socioeconomic fields), contribute to local ownership of the political process in accordance

\footnotetext{
${ }^{47}$ Rep. of the Panel on U.N. Peace Operations, ๆ 48, 55th Sess., U.N. Doc. A/55/305-S/2000/809 (Aug. 21, 2000).

${ }^{48}$ G.A. Res. 1752 (XVII), U.N. GAOR, 27th Sess., , U.N. Doc. A/RES/1752 (XVII) (Sept. 21, 1962); U.N. Charter, arts. 11, 14.

${ }^{49}$ U.N. Charter, arts. 98, 99.

${ }^{50}$ Ioannis Prezas, L'administration de territoires par les Nations unies, THÈSE DE DroIT PUBLIC, Université Panthéon-Assas, 312-21, Paris,Dec. 192007 (Fr.).

${ }^{51}$ WILDE, supra note 6, at 408-17.

52 Edward Mortimer, International Administration of War-Torn Societies, 10 GLOBAL GOVERNANCE, Jan-Mar. 2004, at 7.
} 
with internal and external self-determination, as well as sustain human rights. ${ }^{53}$ Also, the United Nations must respect the notions of territorial integrity and political independence, while enjoying certain privileges within territories.

\section{Legal Timing Interpretation}

Besides the issues of legality and legitimacy, the criterion of temporality is essential because IPBAs are not intended to last. They are defined by qualifiers such as "temporary," "transitional" or "interim." However, this view is highly subjective due to the global indistinctness of the legal sources. The case of the Saar is a strong example, in so far as the administration of the territory by the LoN lasted fifteen years, ${ }^{54}$ and it is worse with the OHR experience in $\mathrm{BiH},{ }^{55}$ which started in 1995 and is not yet finished, as well as with the UNMIK in Kosovo that is still deployed in $2014 .{ }^{56}$ In contrast, the IPBAs in Leticia, western New Guinea, Namibia, Cambodia, Eastern Slavonia and East Timor show that the international presence was established for periods ranging from six months to three years. The only exception that proves the rule in regard to the subjective temporal nature of IPBAs is the sui generis experience of the Free City of Danzig under the protection of the LoN, because its status, as a "Free City," was supposed to be perpetual and this remained in practice until the Nazi invasion. Ultimately, the focal point of the IPBAs' subjective temporal nature is that the reference to a temporary practice helps to legitimize IPBAs since it is not intended to last and should work towards a solution of ownership supported by the local population. ${ }^{57}$

\section{E. Territorial Size}

Among the flexible criteria, the last feature to consider is the size of the territory because almost all IPBAs have taken place in small or medium size territories, with the exception of ONUC. This criterion is reinforced by the difference initiated by another taxonomic criterion-revealed hereafterconcerning the degree of authority: for the most intrusive international administrations, all cases show that direct plenary administrations are established on small territories (Saar, Leticia, Kosovo, and East Timor), while the less intrusive IPBAs are created on territories that can reach a medium size (Namibia, Cambodia, and $\mathrm{BiH}$ ). And, finally, assistance

\footnotetext{
${ }^{53}$ U.N. Charter, art. 1, § 3, art. 55.

54 Alan James, The Peacekeeping Role of the League of Nations, 6 INT'L PEACEKEEPING, Spring 1999, at 154, 155(U.K.).

55 INT’L CRISIS GRP., BOSNIA: EUROPE’s TIME TO ACT (2011).

56 InT’L Crisis GrP., SeRBIA AND Kosovo: The PATH TO NoRmalisation (2013).

${ }^{57}$ Daudet, supra note 25, at 509-12.
} 
missions occur over relatively large areas such as Afghanistan or South Sudan. In all cases, IPBA practice suggests that the intrusion of an international actor within a specific territorial unit can only succeed if the area is small or medium size (the experience of ONUC is not a real success). In addition, with the exception of ONUC and UNTAG, all IPBA experiments have been developed in Europe and Asia, reflecting a Eurocentric vision. To deal with long-term recognition problems or with geostrategic pitfalls (no man's land), international institutions desert a certain kind of area because of a taboo on sovereignty or interference due to a long historical process to become a member of international society. ${ }^{58}$

\section{TAXONOMIC ELEMENTS}

Some key elements to define IPBAs can also be used to build a classification. The territorial status reflects a post-conflict situation or singular cases of self-determination. The legality of such particular missions can be divided between references to those relating to consent and those relating to coercive UNSC Resolutions in virtue of Chapter VII. However, although these definitional characteristics include light classification features, other criteria carry with them the seeds of a taxonomy, while contributing to a lesser degree to refining the definition of IPBA; this is why the primary taxonomic criteria differ from the secondary ones.

\section{A. PRIMARY CRITERIA}

The primary taxonomic criteria are those that mark a rigid IPBA classification. Their boundaries are not blurred.

\section{A Cure for a "Sovereignty Problem" and/or a Remedy for a Governance Vacuum}

First of all, an IPBA is introduced to cope with the pitfalls of sovereignty and/or weak governance: the Leviathan must be saved. IPBAs, therefore, have a common goal, namely the establishment of good governance. The state is the absolute finality, whether it is about a transfer of territory (Saar, Leticia, and Eastern Slavonia), the restructuring of a territory and the revision of a state (Congo and $\mathrm{BiH}$ ) or the path to independence according to the principle of self-determination (West New Guinea, Namibia and East Timor). ${ }^{59}$ In fact, the establishment of an IPBA serves two distinct objectives: on the one hand, it should provide an answer to a governance

\footnotetext{
${ }^{58}$ Mohammed Ayoob, Third World Perspectives on Humanitarian Intervention and International Administration, 10 Global GovernanCE, Jan.-Mar. 2004, at 99.

59 Richard CAPLAN, A NEW TrusteEship? The INTERNATIONAL ADMINISTRATION OF WAR-TORN TERRITORIES 17 (2002).
} 
vacuum, a concept related to the bankruptcy of a state whose structures are deliquescent under the weight of a civil war or a spasmodic intra-state conflict; ${ }^{60}$ and, on the other hand, it involves finding a cure for the painful question of territorial status, which refers to the problem of the identity of the local actor. ${ }^{61}$

In the first case, a response must be provided to the governance conduct (or the lack of conduct). It is essential to restore the Leviathan, as the public authority or the state apparatus has collapsed or is no longer able to exercise its governmental powers over the entire territory. The collapse of the state or its inability to perform its regulatory functions may be the source or the corollary of an alarming situation for international peace and security. In this case, the international actor in charge must re-imagine the state and conduct a particular type of consultation (elections), which aims to determine the actors who are to exercise governmental charges. In this regard two options are viewed. First, an IPBA faces the governance vacuum, which results in the inability of local actors to exercise authority control and administration of their territory (ONUC, UNTEA, UNTAC, and OHR). Second, IPBAs are also established as a direct response to a lack of quality governance within a territory. What is at stake is not the identity of the actor who has administrative control of the territory, but how to run the country: the assistance concerns political governance in the face of uncertainty about territorial status (the Saar, UNTAG, UNMIK, and UNTAET) and/or the effective functioning of the local institutions. All in all, an IPBA is generally established to address the governance vacuum resulting from internal anarchy or corresponding to the movement of the administrative authority. The exercise of the governance function is either reactive because the state structures have collapsed, leaving the state facing a vacuum (Congo, Cambodia, and, to a lesser extent, $\mathrm{BiH}$ ), or proactive as lawlessness in these areas demonstrates the absence of local governance; therefore, the need for an IPBA exercising a governance function appears from the outset (Eastern Slavonia, Kosovo, and East Timor).

In the second case, a solution to the issue of status must be found, especially when it is required to settle a dispute over territorial status, which means that the identity of the "administrator" is at stake; while a state claims sovereignty over a territory, the local population requests its right to self-

\footnotetext{
${ }^{60}$ Helman \& Ratner, supra note 41, at 3-5. This problem appears in the international system when a state is unable to maintain itself as a full member of the international society. Therefore, the state is paralyzed and ineffective: laws are not promulgated or applied; the monopoly of the legitimate use of violence in the enforcement of its order does not exist anymore in the territory and social cohesion flies into pieces. Public authority disappears: the state no longer represents the people and it loses all meaning of social action. Id.

${ }^{61}$ Ralph Wilde, From Danzig to East Timor and Beyond: The Role of International Territorial Administration, 95 Am. J. INT’L L. 586 (2001).
} 
determination. ${ }^{62}$ Anyway, whatever the situation, it may be perceived as a threat to international peace and security, leading therefore to establishing an IPBA (Trieste and Jerusalem projects, UNTEA, and UNTAG). In these circumstances, the international actor must conduct a special type of consultation (plebiscite or referendum), which involves the determination of territorial status (the Saar, Western Sahara, Kosovo, and East Timor), insofar as local actors want to enjoy the functions of government in their territory (the Saar, Leticia, West New Guinea, Namibia, Kosovo, and East Timor). The major question on sovereignty is "who exercises administrative control over the territory," while linking this issue to the appropriation of sovereignty by local actors. Two declension patterns can be provided: the status has been decided and the establishment of an IPBA should implement a statute after the decision (UNTEA, UNTAES, OHR, and UNTAET); otherwise, the status is to be determined, and the IPBA should contribute to converging positions to build a compromise and finalize the territorial status (the Saar, Leticia, UNMIK). The latter model submits to the events because the IPBA must create a better climate in pending further developments that do not depend on the IPBA, namely the status settlement. In addition, another difficulty is added to know if the IPBA should address a matter of domestic or international sovereignty: either the international actor should focus on the settlement of an internal sovereignty dispute, as demonstrated by the case of UNTAES (Eastern Slavonia), when it comes to transferring the territory from the separatist forces to the governmental authority of the Croatian state or an IPBA is established to curb a dispute over national sovereignty (the Saar, Leticia, UNTEA, UNMIK, UNTAET). ${ }^{63}$ Ultimo, with respect to the settlement of a territorial sovereignty dispute, if IPBAs are in place to handle this type of problem, it means that they must provide a response to the defection of the normal model of sovereignty intersubjectively recognized by the international and local actors: IPBAs internally face the lack of a unified government, and they externally must provide a remedy for the sovereign states to resolve their dispute. In this perspective, IPBAs are used as a last resort, when all other diplomatic attempts have failed, and they provide administrative control over the territory, since control by local actors raises problems at the highest level. ${ }^{64}$ Last, but not least, one must keep in mind that situations are not static but evolving, that is to say that sometimes the reality on the ground can take many dimensions explaining the establishment of the IPBA. There may be a tangle of several causes, such as the vacuum of governance, the status issues, as well as isolating the territory, so that further

\footnotetext{
${ }^{62}$ WILDE, supra note 6, at 226-29. The territorial dispute can take three forms: the status of the territory in question (Saarland, Kosovo, East Timor); isolating a territory to avoid the resurgence of disputes between rival states (Danzig, Leticia, $\mathrm{BiH}$ ); or the facilitation of the transfer of a territory of one state to another (West New Guinea and Eastern Slavonia). Id.

${ }^{63}$ SERGe Sur, RELATIONS INTERNATIONALES, 202-04 (2011).

${ }^{64}$ WILDE, supra note 6, at 198-203.
} 
disputes between states do not recur.

\section{Direct Versus Indirect International Administration}

Furthermore, an IPBA is defined by its relation to the population and territory, especially by knowing whether the exercise of governance is direct or indirect. Indeed, territorial administrations in international relations have developed in two ways: either direct, when a foreign actor is directly involved in the internal affairs, or indirect, when a foreign actor lets a local political actor take over the governance of the territory. In this sense, it is essential to differentiate indirect IPBAs from direct IPBAs. ${ }^{65}$ The former are established when a local actor plays an intermediary role between the international actor and the final decision, i.e. from the outset a local governmental structure is in place and the IPBA is governed by a kind of cohabitation (UNTAG, UNTAC, OHR). The latter appear when the international actor is directly involved in the territory without any intermediary actor, which means that the international authority is the only legal and political source at the origin of the mission and no local structure governance interferes in its action (UNTEA, ONUSOM II, UNTAES, UNMIK, UNTAET). It should be noted that after the step of direct plenary authority, a co-governance phase is usually put in place once local institutions are built and political interlocutors are known. Therefore, this criterion does not encroach on the prospect of coadministration that usually develops between the direct plenary phase and local ownership. ${ }^{66}$ Moreover, anomalous models can sometimes be revealed, as evidenced by ONUC and OHR experiences. Anomalies refer to a special form of international administration in which the first operational phase is indirect and the second phase becomes direct under the circumstances (political obstructionism, state failure, civil war, etc.). Establishing direct or indirect IPBAs at the beginning of the mission depends on the level of governance structure failure within the territory. In addition, the size of the territory and the number of inhabitants also influence this choice.

\section{The Degree of Authority}

At the operational level, one of the key criteria for organizing a classification is the degree of authority. Schematically, a continuum can be

${ }^{65}$ Erika de Wet, The Direct Administration of Territories by the United Nations and its Member States in the Post-Cold War Era: Legal Basis and Implications for National Law, 8 MAX PLANCK Y.B. United NAtions L. 292 (2004) (Ger.). This criterion is detected by Erika de Wet, although she does not use it the same way.

66 Michaela Salamun, Democratic Governance in International Territorial AdMinistration: INSTITUTIONAL PREREQUisites FOR DEMOCRATIC GOVERNANCE IN THE CONSTITUTIONAL DOCUMENTS OF TERRITORIES ADMINISTERED BY INTERNATIONAL ORGANISATIONS, 75-96 (2005). 
imagined with, on the one hand, indirect supervision and, on the other hand, plenary direct administration. Supervision is essentially based on the cooperation of local parties to implement the mandate. This type of partial IPBA is particularly vulnerable to obstructionist forces that manifest and attempt to oppose any actual implementation of the policy agenda set by the international actor. ${ }^{67}$ Between these two forms of authority, there is a multitude of degrees such as the "control" that approximates supervision or regulation and marks the midpoint between the two ends of this ideal type. For the most radical forms, the Saar, Leticia, UNTEA, UNMIK, and UNTAET are cases of plenary direct administrations, when an international actor has full executive, legislative, and judicial powers. ${ }^{68}$ However, significantly milder forms can be set up as evidenced by the experience of Danzig where the Commissioner of the League was to indirectly supervise and control the political process. Between these two extremes, namely indirect supervision and plenary direct administration, there is the case of an IPBA starting with supervision powers or indirect control and becoming a plenary direct model because of circumstances based on necessity (la nécessité). This type of evolutionary mission could be defined by the term "incrementalism/gradualism," in particular with the ONUC and OHR experiences: it is a gradual extension of the representative of international society powers. However, the IPBA degree of authority faces three major challenges. First, the commonly prevalent image of a colonial or postcolonial power as a kind of proconsul or viceroy, but this dubious comparison does not make sense, since an IPBA adopts singular checks and balances control mechanisms and is based on the general interest of the local population and international society. The second is essentially linked to the notion of authority, which can lead to abuse as well as excesses towards domination. The third applies to partial IPBAs — with no plenary powers - which can see their room to maneuver hampered by opposition forces. In this sense, the challenge relative to the degree of authority derives from the notion of authority, the balance between authoritarian tendencies and political weakness must be found. In conclusion, on the one hand, there are some plenary IPBAs (the Saar, Leticia, UNTEA, UNTEAS, UNMIK, UNTAET), and on the other hand partial IPBAs (UNTAG, UNTAC, MINURSO). Occasionally, international society uses incremental IPBAs, as evidenced by the experience of ONUC or OHR. This means that situations are not static. Sometimes a partial IPBA can become plenary if the circumstances so require. Usually, a plenary IPBA evolves in practice to a partial form to gradually transmit the governance prerogatives to the new local constituted authorities.

67 Jarat Chopra, Peace-Maintenance: The Evolution of International Political AUTHORITY 13-18 (1999).

${ }^{68}$ CAPLAN, supra note 59, at 14-15. 


\section{The Legal and Practical Relationship Between International and Domestic Actors}

Finally, for a successful IPBA, the relationship between the international political institution and local level is essential: the international actor is no longer a guarantee of absolute legitimacy; the success of an international administration depends on the support and determination of local authorities including its representatives and its population. ${ }^{69}$ Acceptance or systematic opposition from the domestic representatives or the local population is a crucial variable for the IPBA's success or failure. Regarding plenary IPBAs facing conflict and/or governance vacuum, the local population is directly excluded from the outset of the mission, and depending on progress, international agents can involve local ones. For the local population, the IPBA, whose goal is to build or rebuild the state, seems useful at first because it can protect their rights by implementing the fundamental norms of international law. The democratic dimension of such a task provides the local population a right to be represented in the political decision-making sphere. An IPBA also supports mechanisms for the recognition of minorities within a territory defending their rights. However, this relationship is not without difficulty; it may be hampered by systematic opposition: at the beginning of the mission, local sidelining can cause deep resentment (critical neocolonial), which can be exploited by local political spoilers. Furthermore, when no parties are satisfied with the results imposed by the peace agreement and/or by the territorial status arrangement, local obstructionism may undermine the mission. ${ }^{70}$ At first glance, the relationship between international actors and local actors may be one-sided: either the population and local officials approve, like Herod, the function of the international administration when it is perceived as an instrument to put an end to injustice (Herodianism), or the territorial unit's local population and leaders oppose it because they refuse to implement the adopted policy agenda (Zelotism). ${ }^{71}$

However, the link between the international and the local is not so clear because IPBAs have conflicting duties: first, they assume public authority due to the governance vacuum while supporting political pressures of local representatives; secondly, they exercise their powers for the benefit of the relevant territorial unit population, while promoting local ownership. This tension between institutional independence and the duty to transfer authority increases during the mission. It is necessary to find a balance leading to harmony: if the international actor retains powers for too long, the operation

69 U.N. DeP'T. PEACEKEePING OpERATIONS, HANDBOOK ON THE United NATIONS Multidimensional PeACEKEEPING Operations 23 (2003).

${ }^{70}$ Edward Luttwak, Give War a Chance, 78 ForeIgn AfF., July-Aug. 1999, at 36.

${ }^{71}$ ARnOld TOYNBEE, Le MONDE ET L'OCCIDENT, 78-80 (1964); SuR, supra note 63, at 118-24. 
may fail due to the development of a deep resentment of local actors. $A$ contrario, if the international actor does not fully use the powers entrusted and puts an end to the international public authority too quickly, the substantial progress may decline, and the territory can revert to its previous state. So the relationship between the international administrator and local actors may evolve: it is necessary to go beyond international governance and develop people governance. ${ }^{72}$ In other words, it is a "social construct" that takes place in three stages: firstly, the international actor has plenary or partial powers. In this phase, the involvement of local representatives is a prerequisite for stability, viability, and sustainability of the international administration. The difficulty appears in choosing the local interlocutors and in setting up the delegation of powers in the form of advisory bodies. The first pitfall is reinforced by the fact that giving a minimum of power to an unelected local actor may hinder future political participation. In addition, a partial IPBA can encounter major difficulties regarding the sharing of tasks with the local authorities, which initially may negatively influence the international/local relationship. This form of consultation, namely the building of structures of cooperation and power-sharing between international and local actors, appeared in the early IPBA experiments in the twentieth century. Second, in the era of technicians, a technique to achieve self-governance and political participation through this partnership is being established. It is necessary to contribute to local ownership of public power (la puissance publique). In this process, IPBAs generally use a bottom-up strategy, i.e. the international actor starts restoring public authority at the municipal level and, subsequently, it is the central institutions which take possession of public power. ${ }^{73}$ This approach is very useful in situations of post-belligerency: building institutions must begin at the local level, as uncertainty surrounds officials at the central level because they do not know if they are accepted and recognized by local communities and if they are able to implement the IPBA's desired decision. In addition, after a conflict, premature centralization of power may affect the construction of the state: the bottom-up strategy offsets the desire of some ardent partisans to build a strong state with the obligation to develop local capacity (UNMIK and

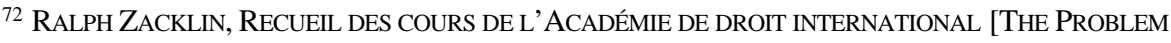
of NAmiBia In InTERnAtional Law] 225-88 (The Hague, Martinus Nijhoff Publishers, Vol. 171, 1981). (In the era of the LoN, self-determination is a way to prevent the resurgence of conflict between states and to defend human rights, as evidenced by the experiences of Danzig or Memel (and to a lesser extent Trieste). Thereafter, systemic changes due to decolonization reorient the notion of self-determination to its current direction based on the free choice of government, independence, sovereignty and democracy (see the case of Namibia in 1967)).

${ }^{73}$ Carsten Stahn, The LaW and PRActice of InTERnational Territorial Administration: VERSAILLES TO IRAQ AND BEYOND 128-29 (2008) The case of post-surrender occupation of Germany is the legendary example of this process.
} 
UNTAET).${ }^{74}$ Although this approach corresponds somehow to an ideal type concerning the local ownership process, implementation is more difficult, as evidenced by the bad judgments on local actors, as well as the fact that sometimes the reverse approach is valued: the top-down strategy, where everything starts from the center to the local, which leads to frustration on the part of local actors, insofar as the results within central institutions are not necessarily visible from the outside, not to mention the lack of involvement and transparency problems (OHR). ${ }^{75}$ Thirdly, local institutions take full control of public authority after elections and/or the adoption of a constitutional architecture for the polity. ${ }^{76}$ This is the complete local ownership of the political process. Indeed, international institutions begin to consider an exit strategy, which starts to be implemented after elections or popular consultation. However, during this phase, the IPBA faces two difficulties: a) it is dangerous to hold elections prematurely; ${ }^{77} \mathrm{~b}$ ) the elections are not enough because we must develop a democratic culture in the long term based on constitutional liberalism. ${ }^{78}$ The praxis shows that this phase is poorly negotiated by the international actor: the disengagement is so disorderly and the international actor forgets (or is unwilling) to establish an assistance mission to continue to support the territorial unit recovery, which creates postoperative instability (ONUC, UNOSOM II, UNTEA, and UNTAC). Monitoring is needed. ${ }^{79}$

\section{B. Secondary Criteria}

Following the analysis of the primary criteria, other less revealing elements are used to refine the classification. They are considered secondary, as their different specificities intermingle which reduces their scope in the context of a taxonomy.

\section{Administrare: Political and/or Policy Institution}

Basically, the term “institution” has a double meaning: on the one hand,

74 Regulation No. 2000/45 on Self-Government of Municipalities in Kosovo, UNMIK/REG/2000/45 (Aug. 11, 2000); Regulation No. 2000/13 on the Establishment of Village and Sub-District Development Councils for the Disbursement of Funds for Development Activities, UNTAET/REG/2000/13 (Mar. 10 2000).

75 Karin Oellers-Frahm, Restructuring Bosnia-Herzegovina: A Model with Pit-Falls, 9 MAX PlanCK Y.B. United NATIONS L. 180, 194-204 (2005) (Ger.).

76 AnN HironaKa, NeVERENDing Wars: The InTERnAtional COMMUnity, WeAK States and THE PERPETUATION OF CIVIL WAR 10-11 (2005).

77 Roland Paris, At WAR’s END: BuIlding PeACE AFter Civil CONFLICT 187-88 (2004).

${ }^{78}$ FAREED ZAKARIA, THE FUTURE OF FREEDOM: ILLIBERAL DEMOCRACY AT HOME AND ABROAD 3751, 257-64 (2004).

${ }^{79}$ Mark Baskin, Between Exit and Engagement: On the Division of Authority in Transitional Administrations, 10 GLOBAL GovernanCE, Jan.-Mar. 2004, at 119-37. 
it includes a material and physical sense-it refers to an institutionalized entity such as an international organization; on the other hand, it has a nonmaterial and intangible value referring to a sui generis established practice, ${ }^{80}$ as customary law may be in international relations. It is in this last sense that an IPBA is a political institution. By adopting a teleological vision, IPBA perceived as a political institution would be an established practice centered on political affairs, which means that it is an institution based on a collective purpose which is purely political. An IPBA is a political institution because it is intended to standardize a political, security, social, or conflict situation. It acts as a substitute for the local standard of territorial administration: it compensates for the failure of la puissance publique. In addition, this sovereign substitute (substitut régalien) may, as it progresses, involve the local actors, so that they take ownership of the political transition process. ${ }^{81}$

Faced with a vacuum or qualitative governance failure, an IPBA can implement several types of policy divided into four categories. The first government policy of the IPBA is used to settle a territorial dispute and promote status (free city, state, sub-state territorial unit, or future status to be determined). The identity of the actor is not questioned, but it is the way of governing that is questionable. Concretely, it is a matter of governance either to reach an agreement on the future status (establishment of an international government to promote the future status), ${ }^{82}$ or to support the enactment of the statute, ${ }^{83}$ or to ensure the continuation of the status adopted by the agenda. ${ }^{84}$ The second government policy of an IPBA is to give effect to the functioning of institutions according to the democratic model, respecting the rule of law and pursuing a liberal economic policy based on expertise. ${ }^{85}$ It is common to observe the blocking of the machinery of the liberal democracy model in ethnically heterogeneous societies; this is why the international neutral actor is best suited to promote the principle of impartiality compared to other forms

${ }^{80}$ ANDRÉ AKoun \& PierRe ANSART, DictionnAIRE DE SOCIOLOGIE, 286-87 (1999).

${ }^{81}$ CAPLAN, supra note 59, at 10.

${ }^{82}$ Treaty of Versailles pt. III, § IV, arts. 45-50, June 28, 1919, 225 Consol T.S. 188; G.A. Res. A/RES/2248 (S-V), para. 1 (May 19, 1967); S.C. Res. 1244, ๆๆ 10-11, U.N. Doc. S/RES/1244 (June 10, 1999) (The establishment of the Saar IPBA and the wait for a final status in 1935, and the example of the creation of the United Nations Council for South West Africa in 1967.).

83 S.C. Res. 1272, U.N. Doc. S/RES/1272 (1999) (Oct. 25, 1999); General Framework Agreement for Peace in Bosnia and Herzegoivina, in letter dated 29 Nov. 1995 from the Permanent Representative of the United States of America to the United Nations addressed to the Secretary-General, U.N. Doc. A/50/790-S/1995/999 (Nov. 30, 1995).

${ }^{84}$ S.C. Res. 435, U.N. Doc. S/RES/435 (Sept. 29, 1978); Final Act of the Paris Conference on Cambodia, in letter dated 30 Oct. 1991 from the Permanent Representatives of France and Indonesia to the United Nations addressed to the Secretary-general, U.N. Doc. A/46/608S/23177 (Oct. 30, 1991).

${ }^{85}$ Susan L. Woodward, Construire l'Etat: légitimité internationale contre légitimité nationale?, 28 CRITIQUE INTERNATIONALE 139 (July-Sept. 2005) (Fr.). 
of territorial administration (trusteeship, occupation, etc.). The state construction policy can be sub-divided into three categories: the first one focuses on the effectiveness of the political institutions created (UNTAC and UNTAES); the second one applies to IPBAs, which ensure the establishment and the functioning of institutions and, thereafter, hold consultations on the territorial status (the Saar, UNMIK, and to a lesser extent UNTAET); the third one attends to the functioning of institutions and so elections must be held to give effect to the government of these territories (OHR and UNTAG). This policy approach based on the political concept of state building ${ }^{86}$ should promote the existence of the state and a particular model of governance organized around the concepts of democracy, rule of law, and market economy. ${ }^{87}$ It occurs in two scenarii: either when a territorial unit is separated from a state, or when a state is affected by decay and bankruptcy syndromes, plunging into anarchy. This political process implemented by an IPBA consecrates the state model of the West, based on the Westphalian state principles $^{88}$ as well as political and economic liberalism. The third governance policy involves migration control: this government program is found in all cases, whether it is a matter of status (the Saar, West New Guinea, and Kosovo), which can lead to migration, or it is linked to a vacuum of governance and anarchy which lead inexorably to population movements. ${ }^{89}$ Therefore, the IPBA supports security, political and socio-economic issues concerning refugees and IDPs. The fourth governance policy is rather marginal in terms of empirical verification, but it focuses on the exploitation of natural resources, as evidenced by the episode of the Saar (exploitation of natural resources by France as compensation for WWI) and by the agreement concerning the exploitation of Greater Sunrise during the UNTAET mandate on East Timor. ${ }^{90}$

To cope with the pitfalls of sovereignty, IPBAs often must curb disputes: it is a mechanism for the implementation of dispute resolution. The International Commission of the Saar had at first to implement the Treaty of Versailles; then it had to avoid any resurgence of tension between the French and German positions. Concerning the implementation of the clauses of the

${ }^{86}$ CAPLAN, supra note 10 , at $2-3$.

${ }^{87}$ Fox, supra note 3, at 142-73.

${ }^{88}$ AidAN HEHIR, HuMANITARIAN INTERVENTION AFTER KOSOVO: IRAQ, DARFUR AND THE RECORD of Global Civil Society 30 (2008); Robert Jackson, The Global Covenant: Human CONDUCT IN A WORLD OF STATES, 172-82 (2000); Outi Korhonen, International Governance in Post-Conflict Situations, 14 LEIDEN J. INT’L L. 495, 527-28 (2001) (Neth.).

89 Gil Loescher \& James Milner, Protracted Refugee Situations: Domestic and INTERNATIONAL SECURITY IMPLICATIONS 24-34 (2005).

90 Treaty of Versailles, supra note 82, at art. 49; Ghislain Poissonnier, Le Timor oriental et l'espoir contrarié d'un grand soleil levant, 132 JouRNAL DU DROIT INTERNATIONAL 762, 763-66, 769-80 (2005) (Fr.); Ralph Wilde \& Barbara Delcourt, Le retour des protectorats. L'irrésistible attrait de l'administration de territoires étrangers, in LA GUERRE D'IRAK: PRÉLUDE D'UN NOUVEL ORDRE INTERNATIONAL? 224-27 (Barbara Delcourt, Denis Duez \& Eric Remacle eds., 2004) (Brussels). 
Treaty of Versailles, it can also refer to the Free City of Danzig and Memel territory, insofar as it was necessary to ensure practical solutions to disputes in the aftermath of the First World War. The experience of the LoN Commission in Leticia is le cas par excellence of the resolution of both dispute and conflict: the functional mechanism of the LoN had to create a neutral space (Leticia), so that both parties would calm down and come to a compromise. In the Saar and Kosovo, the international mission had to strike a settlement on the future status. In Eastern Slavonia, the IPBA had to settle the territorial dispute between the Croatian government and the Serb militias ensuring full compliance with the 1995 Agreement. ${ }^{91}$ So it would seem that IPBAs are intended to implement (or to obtain) the agreements that provide a definitive solution to the question of the status of certain territories.

However, limiting the IPBA's action to this question overshadows another part concerning self-determination and sovereignty. It is obvious that external self-determination is the result of an agreement, but the analyst should not neglect the internal self-determination, which is identifiable as peoples' rights in the territories, i.e. it concerns the rights of minorities, the right to free and fair elections, and the right to participate in public life. The principle of self-determination contributes to the justification of IPBAs. In this sense, the IPBA is a mechanism of synthesis of the two hallmarks of selfdetermination, namely external self-determination on the status of the territory and internal self-determination on the rights of the people within the territory. ${ }^{92}$ In addition, IPBAs are also responsible for managing internal disputes between the local actors, international actors and neighboring states (UNTAG, UNTAC, OHR, UNMIK, UNTAET).

Ultimately, an IPBA is a political response either to a governance problem, i.e. it is the conduct or lack of conduct of public power which is a source of difficulty (quality governance exercised), or to a sovereignty problem because it affects the identity of the actors who perform the functions of government in a territory. What characterizes all forms of IPBA is that they are, in essence, political: either they provide the political functioning of the territory (vacuum of governance), or they displace local actors in relation to the exercise of the sovereign prerogatives (prérogatives régaliennes) in a situation related to a sovereignty problem because it is the identity of the actor who has administrative control over the territory, which is a source of tension. Therefore, an IPBA fulfills the function of international public service, as an international actor provides a service to a state and a population of a territory acting in the interests of the inhabitants of the state

${ }^{91}$ Basic Agreement on the Region of Eastern Slavonia, Baranja and Western Sirmium, in letter dated 15 Nov. 1995 from the Permanent Representative of Croatia to the United Nations addressed to the Secretary-General, U.N. Doc. A/50/757-S/1995/951 (Nov. 12, 1995).

${ }^{92}$ Rüdiger Wolfrum, International Administration in Post-Conflict Situations by the United Nations and Other International Actors, 9 Max PlancK Y.B. United NATIONS L., 649, 678-80 (2005) (Ger.). 
concerned and, more broadly of international society, since it is about a threat to international peace and security. On the one hand, it ensures the survival, maintenance, and/or development of state units in the international system, to preserve international peace and security by defending the general interest of international society; on the other hand, it works for the interests of people in an area that experiences governance or sovereignty problems-a substitute for local actor governance emphasizing the obligations of the state under international law. In addition, an IPBA, whether plenary or partial, performs the functions of a public authority (puissance publique) in the territory for the local population; de facto, it is highly intrusive. ${ }^{93}$ The exercise of regulatory authority by IPBAs results in extensive legislative (law-making) and executive powers. Regulations adopted by IPBAs are applicable to the international actor in the territory as well as to the legal system of the territory, which means that the acts are directly applicable in the territory at the local level, while they are enacted within the international sphere. ${ }^{94}$ However, the analysis of the IPBA structure as a political institution must be completed because even if the ultimate goal is political and legal, it is nevertheless a fact that a response to a form of latent insecurity should be given. So within an IPBA two components frequently coexist, one civil, the other military.

\section{Differentiations Between Ante and Post-Cold War}

Another secondary taxonomic criterion is the differentiation between experiences before the end of the Cold War and those that followed. Distinctions are based on the proliferation of international actors, multifunctionality, exceptionalism, or increased powers of the UNSC and the UNSG, as well as the exit strategy. The first characteristic that differentiates IPBAs pre- and post-Cold War is the proliferation of international actors involved in this type of project to respond to challenges of sovereignty or governance failure. ${ }^{95}$ First, it would be unthinkable in the postcolonial era to consider that a state can administer a territory in which it is not sovereign without referring to international humanitarian law, especially the law of occupation. Second, even for a single international institution, the cost of

\footnotetext{
93 RoBert Kolb, GABriELE PORRETTO \& SylVAin Vite, L’APPLICATION DU DROIT INTERNATIONAL HUMANITAIRE ET DES DROITS DE L'HOMME AUX ORGANISATIONS INTERNATIONALES: FORCES DE PAIX ET ADMINISTRATIONS CIVILES TRANSITOIRES 111 (2005).

94 Stahn, supra note 9, at 145-48, 156-58. See also Carsten Stahn, International Territorial Administration in the former Yugoslavia: Origins, Developments and Challenges Ahead, 61 ZEITSCHRIFT FÜR AUSLÄNDISCHES ÖFFENTLICHES RECHT UND VÖLKERRECHT 107, 154-61 (Ger.) ("These legislative acts are international regulations that apply directly to the domestic sphere of a territorial unit, thereby becoming pseudo-national acts.”).

95 Mats Berdal \& Richard Caplan, The Politics of International Administration, 10 GLOBAL GOVERNANCE 1, Jan.-Mar. 2004, at 1-5.
} 
providing a response to a sovereignty dispute and/or poor governance by the establishment of an IPBA would be exorbitant. ${ }^{96}$ Therefore, there is a multitude of international organizations working in favor of IPBAs since the burden-sharing is easier via different international institutions. Indeed, the United Nations is the great architect for international peace and security, but it can resort to regional organizations such as the North Atlantic Treaty Organization (NATO), the Organization for Security and Co-operation in Europe (OSCE), the European Union (EU), the African Union, as well as the United Nations Civilian Police (CIVPOL) to apply cosmopolitan law principles ${ }^{97}$ or provide assistance in the field of security sector reform $(\mathrm{SSR})^{98}$ after an intervention. In order to provide an opinion on a question of international law or clarify massacres, the United Nations uses international institutions such as the International Court of Justice (ICJ), the Office of the United Nations High Commissioner for Human Rights (OHCHR), the international criminal tribunals (International Criminal Tribunal for the former Yugoslavia - ICTY), and the International Criminal Court (ICC). In these areas, one must also take into account the activities of the International Committee of the Red Cross (ICRC), the Council of Europe and the role of the European Court of Human Rights (ECHR). To deal with socioeconomic issues after a humanitarian tragedy, the United Nations interacts with many agencies, such as the Office of the United Nations High Commissioner for Refugees (UNHCR), the World Food Programme (WFP), the United Nations Children's Fund (UNICEF), the International Organization for Migration, the United Nations Human Settlements Programme (Habitat), the Food and Agriculture Organization of the United Nations (FAO), the United Nations Development Programme (UNDP), the World Health Organization (WHO), the International Labour Organization (ILO), or the United Nations Educational, Scientific and Cultural Organization (UNESCO). Finally, in a globalized world, international society assistance depends on the support of international financial institutions (IFIs) to contribute to reconstruction and development: this is the function of the International Monetary Fund (IMF), the World Bank, as well as non-governmental organizations (NGOs), regional or national organizations specializing in this sector, such as the European Agency for Reconstruction, the European Bank for Reconstruction and Development (EBRD), the European Investment Bank (EIB), the Association of Southeast Asian Nations (ASEAN), the Asian Development

${ }^{96}$ CAPLAN, supra note 10 , at 33-41.

97 Simon Chesterman, Transitional administration, STATE-Building and tHE United Nations 339 (2004); David Held, Democracy and the Global Order. From the Modern State to Cosmopolitan Governance 270-83 (2004); Carsten Stahn, Governance Beyond State: Issues of Legitimacy in International Territorial Administration, 2 INT'L. ORGANIZATIONS L. REV. 9, 9-14, 50-56 (2005) (Neth.).

98 Security Sector Reform and Post-Conflict Peacebuilding, 1-14 (Albrecht Schnabel \& Hans-Georg Ehrhart eds., 2005). 
Bank (ADB), the Organization of Islamic Cooperation (OIC), the Organization of Petroleum Exporting Countries (OPEC), the United States Agency for International Development (USAID), the U.S. Office of Foreign Disaster Assistance (OFDA), the Japan International Cooperation Agency (JICA) or the Australian Agency for International Development (AusAID). In addition, post-Cold War IPBAs differ from previous experiences because they are more developed multi-functionally and are a practice of exceptional order, in particular for the plenary forms. IPBAs must establish and maintain public order and security, provide humanitarian assistance, resettle refugees and IDPs, ensure partial or plenary functions of civil administration, build an institutional system (including the creation of a civil society), organize free and fair elections, and rebuild the local economy according to liberal principles. Moreover, plenary IPBA practice in the post-Cold War correlates with the internationalization of the social contract, ${ }^{99}$ i.e. international society is particularly interested in how nations are governed and the relationship between the Leviathan and its population. This is particularly highlighted by the Report of the Panel on U.N. Peace Operations (Brahimi Report). ${ }^{100}$ Exceptionalism is a major feature of post-Cold War IPBAs, as IPBA implementations are not frequent. The post-Cold War exceptionalism is characterized by extreme powers given to international administrators, especially in the case of plenary international administration. ${ }^{101}$ This particular reading of post-Cold War IPBAs is reflected in the Brahimi Report, which focuses heavily on the uniqueness of these experiments after $1990^{102}$ because IPBAs, whether partial or plenary, go far beyond the simple assistance mission-either supervising and controlling the political, social, and legal process in a situation of post-belligerency or directly conducting the puissance publique activities. Another feature that distinguishes IPBAs pre- and post-Cold War is identifiable with the increased role of the UNSC. Since the early nineties, there has been an increase of UNSC involvement, as evidenced by the growing references to Article 39 of the U.N. Charter in many different situations including massive flows of refugees in civil wars and human rights violations by a government against its own people within

\footnotetext{
${ }^{99}$ Fox, supra note 3, at 72.

${ }^{100}$ Rep. of the Panel on U.N. Peace Operations, supra note 47, ๆף 18-19.

${ }^{101}$ WILDE, supra note 6, at 10-12.

102 Rep. of the Panel on U.N. Peace Operations, supra note 47, I 77 ("These operations face challenges and responsibilities that are unique among United Nations field operations. No other operations must set and enforce the law, establish customs services and regulations, set and collect business and personal taxes, attract foreign investment, adjudicate property disputes and liabilities for war damage, reconstruct and operate all public utilities, create a banking system, run schools and pay teachers and collect the garbage - in a war - damaged society, using voluntary contributions, because the assessed mission budget, even for such 'transitional administration' missions, does not fund local administration itself. In addition to such tasks, these missions must also try to rebuild civil society and promote respect for human rights, in places where grievance is widespread and grudges run deep”).
} 
its territory. ${ }^{103}$ This new posture has been accepted since An Agenda for Peace $^{104}$ and the Supplement to An Agenda for Peace. ${ }^{105}$ This broad interpretation of the UNSC powers of intervention is linked to the evolution of peacekeeping missions that no longer consist in classic peacekeeping (interposition) but correspond to multifunctional operations. In addition, the role of the UNSG is more and more important on operational and normative levels. ${ }^{106} \mathrm{~A}$ final distinction criterion is the international awareness regarding the exit strategy. The twentieth century reflects the classic case for IPBA termination, that is, at the end of the international mandate, no international mission takes over: either the territory becomes independent (Namibia), or it is attached or transferred to a sovereign state (Leticia, West New Guinea), or a state recovers its sovereign rights (the Saar, Congo). However, since the end of the Cold War, international actors have begun to consider the importance of postoperative follow-up, with the establishment of an assistance mission at the termination of the IPBA. In sum, the post-Cold War IPBAs are unique, insofar as they highlight the increasing role of the UNSC in the practice of these forms of international administration, in which the UNSG plays an important role concerning both normative and operational aspects. The highest official of the Organization is the synthesis between the mandate and the operation. $\mathrm{He}$ is also the link between the various international bodies involved in this type of multifunctional exceptional project.

\section{CONSEQUENCES OF CONTEMPORARY SUBSEQUENT PRACTICE}

Following the observation of different factors and elements specific to IPBAs, ataxonomy appears possible, although the pitfalls of systematisation are numerous. All these observations will be particularly interesting to understand the contemporary evolution of IPBAs.

\footnotetext{
103 U.N. Charter art. 39.

${ }^{104}$ U.N. Secretary-General, An Agenda for Peace: Preventive Diplomacy, Peacemaking and PeaceKeeping: Rep. of the Secretary-General, U.N. Doc. A/47/277-S/24111 (June 17, 1992).

105 U.N. Secretary-General, Supplement to An Agenda for Peace: Position Paper of the SecretaryGeneral on the Occasion of the Fiftieth Anniversary of the United Nations, U.N. Doc. A/50/60S/1995/1 (Jan. 3, 1995).

106 Kolb, Porretto \& Vite, supra note 93, at 102 (« La délégation de pouvoirs aux États, non prévue par la Charte, est contrecarrée, lors de la mise en œuvre d'une action “collective”, par un rôle directif et de contrôle assuré non seulement par le CSNU, mais aussi par le Secrétaire général. Ce dernier devient ainsi un organe de synthèse des pouvoirs de l'organisation » ["The delegation of powers to the states not covered by the Charter, is thwarted when the implementation of a "collective" action by a directive role and control ensured not only by the UNSC, but also by the Secretary General. It becomes an organ of synthetic powers of the organization”]).
} 


\section{A. The Pitfalls of Contemporary Taxonomy}

First of all, several scholars have attempted to draw the outlines of IPBA classification, but their attempts were unsuccessful, inasmuch as they encountered a fundamental obstacle, i.e. the natural tendency to over-extend the concept to promote each particular type and bring into the notion of IPBA the experience of peace operations, which do not belong to IPBAs. ${ }^{107} \mathrm{~A}$ first illustration of IPBA modelling which is too wide appears with a multimorphology developed by Gerald B. Helman and Steven R. Ratner. These authors see three different types within this concept: (i) assistance missions, when the local government remains the legal authority and international agents support the domestic administration; (ii) co-administration, when the international administration has certain sovereign prerogatives in agreement with the central government of the territory that maintains its authority; (iii) intrusive international administrations, when the international actor has full authority over a territory. ${ }^{108}$ Another classification proposed by Carsten Stahn encounters the same weakness, i.e. broadening the concept too much to incorporate other models such as occupation, to deeply emphasize different categories within it. In this classification, the conceptualization of practice is overly broad because it includes assistance missions (thereby limiting the IPBA specificities to relative peace operations), international administrations, as well as the highly singular case of the occupation of Iraq in 2003. ${ }^{109}$

Furthermore, the second major limitation to building a harmonious taxonomy comes from the specificity of each mission ${ }^{110}$ and the specific context of each case as taught by Aronian and Weberian interpretive sociology. ${ }^{111}$ In this context, it is clear that IPBA practice reflects a deep diversity of empirical settings. In other words, this reflects varying degrees of international administration depending on the duration, the period and the interest of the mission, and the major powers which seek to establish this kind of conflict resolution mechanism (context offers a multitude of opportunities), as well as depending on the configuration of the international system. Moreover, some criteria on the different forms of IPBA are difficult to use to create a classification since all the possibilities may be employed by the IPBA. As a demonstration, referring to the different policies pursued by an IPBA (status, state-building, migration or resources) is not necessarily

\footnotetext{
${ }^{107}$ Michael W. Doyle, War Making and Peace Making: The United Nations Post-Cold War Record, in Turbulent Peace: The Challenges of Managing International Conflicts 529, 546-54 (Chester A. Crocker, Fen Osler Hampson \& Pamela Aall eds., 2001); Chopra, supra note 67, at 16. ${ }^{108}$ Helman \& Ratner, supra note 41, at 13.

${ }^{109}$ STAHN, supra note 73, at 395-406.

${ }^{110}$ CAPLAN, supra note 59, at 10.

111 Béatrice Pouligny, Ils nous aVAient promis la paiX: Opérations de L’ONU eT POPULATIONS LOCALES 18-24 (2004).
} 
relevant for classification because several IPBAs practice the above mentioned categories of public policy.

Before building a taxonomy of IPBAs, it is necessary to emphasize that the boundaries between the definitional and taxonomic criteria are porous. Some of them globally contribute to defining an IPBA while they also contribute to a lesser extent to the classification of the notion, and others primarily participate in classifying the different morphologies of IPBAs but can also refine the definition of an IPBA. About the principles facilitating definition, they also serve for minor classification. Indeed, the "status of the territory" may refer either to a territorial unit within a state or to a territorial unit of self-determination. The "legality" regarding the IPBA's deployment implies consent or a coercive action related to a resolution of a major international institution; sometimes both overlap and it is even referred to as coercive consent. The term "post-belligerency" can apply to setting up a mission in an interstate or an intrastate post-conflict situation or also after belligerency, which is simultaneously internal and external. The reference to a "temporary practice" is not sufficiently explicit insofar as it can be really short term (six months to two years), medium term (five years), or long term (more than ten years). The geopolitical criterion of the size of the territory is also variable: there are very small territories, others are medium-sized and some are exceptionally big, such as ONUC in Congo.

\section{B. An Empirical Classification: The Subsequent Practice}

To highlight the different types of IPBAs, major criteria have to be taken into consideration: the degree of authority (distinguishing plenary forms, gradual and partial forms) and direct or indirect administration. At the start, there are three major models for the powers granted to an international actor, starting with full powers or "emergency powers" to reach a compromise situation where prerogatives are shared. Between these two extremes, international society occasionally uses incremental IPBAs (from conciliation to authoritarian governance). ${ }^{112}$ However, it should be noted that the situations are not static. ${ }^{113}$ Furthermore, to determine the impact of the plenary or partial character, it is necessary to know if the international administration is direct or indirect: so there would be direct plenary, indirect plenary, direct incremental, indirect incremental, direct partial, and indirect partial IPBAs.

Having underscored plenary/partial and direct/indirect IPBAs, it is necessary to look at both ends of the mission in terms of specific causes for the establishment of the IPBA. Firstly, to cope with the vacuum or

\footnotetext{
112 The result: Plenary (Saarland, Leticia, UNTEA, Namibia 1967 UNTAES but unused powers), gradual (ONUC and OHR in BiH), and partial (Danzig, Memel, UNTAG, UNTAC, MINURSO, UNOSOM II).

${ }^{113}$ CAPLAN, supra note 10 , at $17-18$.
} 
qualitatively weak governance, referring to "builder" IPBAs is possible, so as to order the international system by creating or reforging states. ${ }^{114}$ Secondly, to address the problem of territorial sovereignty, one can speak of "mediation" IPBAs, insofar as they must either resolve a territorial dispute (resolution of territorial status, neutralization of status or territorial transfer) or work towards decolonization. ${ }^{115}$ Nevertheless, it should be noted that, in some cases, the problems of sovereignty and governance can be linked (the Saar, BiH and Kosovo), which weakens the scope of this taxonomic criterion. So twelve major types of IPBA stand out:

- direct plenary builder IPBAs (the Saar, the U.N. Council for Namibia and UNTAES, UNMIK),

- indirect plenary builder IPBAs (OHR from 1998 when the High Representative obtained the "coercive" Bonn powers),

- direct plenary mediation IPBAs (the Saar, Leticia, UNTEA, the U.N. Council for Namibia, UNTAET),

- indirect plenary mediation IPBAs (none),

- direct incremental builder IPBAs (ONUC),

- indirect incremental builder IPBAs (OHR),

- direct incremental mediation IPBAs (none),

- indirect incremental mediation IPBAs (OHR),

- direct partial builder IPBAs (UNOSOM II),

- indirect partial builder IPBAs (UNTAG, UNTAC),

- direct partial mediation IPBAs (none),

- and indirect partial mediation IPBAs (MINURSO).

The emphasis of these categories is now made from two key elements, namely the IPBA's nature and objectives. Another additional key criterion to build a multi-morphology IPBA model would have been with no doubt the perception of the IPBA action by local actors, both officials and the local population (Zelotism versus Herodianism). However this factor is so human that it is difficult to build a taxonomy taking it into account, especially because the perception cannot be uniform according to the different local actors, and it also depends on the IPBA's time scale. In addition, one could also add and complicate the different kinds of IPBA with other possibilities of model duplication by adding the distinction between forms ante and postCold War, but it seems that the IPBA classification loses clarity and would

\footnotetext{
114 Armin von Bogdandy, Stefan Haubler, Felix Hanschmann \& Raphael Utz, State-Building, Nation-Building, and Constitutional Politics in Post-Conflict Situations: Conceptual Clarifications and an Appraisal of Different Approaches, 9 MAX PLANCK Y.B. United NATIONs L., 579, 579-83 (2005) (Ger.).

${ }^{115}$ WILDE, supra note 6, at 147-51, 188-89.
} 
not find empirical approbation. ${ }^{116}$ Besides, other elements used to define the concept could also help to boost the empirical taxonomy, but it is useless because the multiplication of taxonomic criteria imposes a heavier understanding of the concept and of the different forms without providing a better ranking of experiments. It is not advantageous to "clutter" the taxonomy with other characteristics such as international actors, legality, legitimacy, temporary practice, or the territorial size. However, a sensible observer might consider that two definitional criteria, post-belligerency (internal and external) and the temporary practice (short, medium, and long term) further sharpen the categorization process. This is true, but this accumulation of configurations does not necessarily find an echo in the subsequent practice.

\section{Cycles Theory of Plenary Forms of IPBA}

Beside all the features common to plenary or partial IPBAs in the postCold War era, such as the proliferation of international actors, multifunctionality, the role of the UNSC and the Secretariat, the design of exit strategies, other features allow us to draw attention to the most intrusive plenary IPBAs. The first two distinctive signs of plenary IPBAs in the postCold War have already been developed in advance: on the one hand there is the exceptionalism of this type of intervention in a territorial unit and the emergency powers ${ }^{117}$ conferred on an international actor who has to construct or reconstruct a state by engaging in all public decisions, and on the other hand, the exacerbated multifunctionality, which means that the involvement of international actors in the puissance publique affects all areas of public life (security, socioeconomic and institution-building, refugees and IDPs). Another element common to plenary IPBAs in the post-Cold War is their evolutionary character: originally, these international administrations are exclusive, then a system of shared responsibilities and prerogatives is set up to facilitate local ownership in the end. A final feature stems from the fact that these experiences are halfway between peacekeeping in the broad sense and a political process reflecting both the building of sustainable peace and the shape of a democratic state based on the rule of law. It is simply not a question of implanting state and administrative structures in regions subject to anarchy but of participating and ensuring the development of a liberal political system based on the norms of international law and human rights. In this perspective, radical IPBAs of the post-Cold War are a synthesis of peace-

116 See the pitfall of Paul F. Diehl, Daniel Druckman \& James Wall, International Peacekeeping and Conflict Resolution: A Taxonomic Analysis with Implications, $42 \mathrm{~J}$. CONFLiCt RESOL. 33, 39-40 (1998).

117 François SAint-Bonnet, L'Etat D’EXCEPTION (2001); Oren Gross, The Normless and Exceptionless Exception: Carl Schmitt's Theory of Emergency Powers and the Normexception Dichotomy, 21 CARDOZO L. REv. 1825 (2000). 
making and post-conflict peacebuilding; this is why, in regard to their respective legal framework, they are based on Chapter VII of the U.N. Charter. ${ }^{118}$

Empirically, in the last decade of the twentieth century, the evolution towards a highly intrusive form of plenary IPBAs was achieved by pragmatism, depending on the difficulties of practice. The pivot is somehow the experience in $\mathrm{BiH}$ : after the Dayton Agreement, international society (marginalizing the United Nations) set up an indirect administration via the OHR, i.e. the international mission cohabits with the government of the host state perceived as unable to assume the exercise of public authority without international support. Originally, it was simply an indirect administration of supervision and control. However, to deal with latent obstructionism, powers of the High Representative (HR) were reinforced in 1998 to consolidate the Bosnian state; this is why the IPBA changed shape: it passed from a model of supervision and control to an intrusive one: the HR (international authority) became more and more involved in the decision-process as well as in the legislative, executive, judicial, and administrative process. ${ }^{119}$ So the juxtaposition of a state model and an international model is observed, which results in the intervention of an authority of an international legal system within a national legal system. The overlap between a national government and an IPBA is defined by the concept of functional duality. ${ }^{120}$ Pragmatism and directions toward a plenary model developed by the international society of states to deal with latent obstructionism in $\mathrm{BiH}$ close to the EU borders strongly influence the following experiences, particularly in Kosovo and East Timor from 1999. UNMIK experimentation in Kosovo is the model par excellence of a highly intrusive plenary IPBA, which is implanted after a dispute over control of the territory, leaving the future status pending for a while. ${ }^{121}$ For UNTAET in East Timor, the structure of the IPBA was similar to the one of UNMIK (although the civilian and military aspects are overseen by the same structure) and the international administration had to conduct the self-determination territorial unit to independence in accordance with the referendum of 1999, even if the territory fell into oblivion for twenty-five years. ${ }^{122}$

In the early twenty-first century, international society abandons plenary IPBAs, and assistance missions are in the ascendant. This is partially due to a highly singular and problematic case, the occupation of Iraq after 2003. The overthrow of Saddam Hussein and the establishment of a Coalition

\footnotetext{
118 Kolb, Porretto \& Vite, supra note 93, at 108.

119 Oellers-Frahm, supra note 75, at 207-12.

${ }^{120}$ Alvarez, supra note 22, at 634-35.

${ }^{121}$ Jürgen Friedrich, UNMIK in Kosovo: Struggling with Uncertainty, 9 MAX PLANCK Y.B. United NATIONS L. 225, 233-50 (2005) (Ger.).

122 Joel C. Beauvais, Benevolent Despotism: A Critique of UN State-Building in East Timor, 33 N.Y.U. J. INT’L L. \& POL. 1101 (2001).
} 
Provisional Authority (CPA) by the United States and its allies led to the resurgence of old concepts in a postmodern form: the renaissance of Western colonialism. ${ }^{123}$ Following the intervention, a multinational operation was initially oriented through a conventional occupation respecting the Hague Convention and the Fourth Geneva Convention, then through a hybrid territorial administration, when it obtained some recognition by UNSC Resolutions 1483 and 1511, which also established a Special Representative of the Secretary General (SRSG) for humanitarian coordination and support of the U.N. mission. ${ }^{124}$ The major weakness resulting from Resolution 1483 was the limit to converge the standards relating to the law of occupation with the principles of peacebuilding, which left considerable room for interpretation about what type of norm takes ascendancy over the other, thereby nurturing the idea of a transformative occupation law. ${ }^{125}$ Indeed, the occupying powers justified their extensive agenda of reforms by referring both to the law of occupation and UNSC Resolutions. In fact, the occupation lasted about eighteen months between April 9, 2003, when foreign forces entered Baghdad, and June 28, 2004, when the CPA was dismantled. ${ }^{126}$ The occupation of Iraq demonstrates the negative evolution of the regime of occupation because the occupying powers sought to integrate it within the U.N. framework. The occupying powers relied on the participation of a U.N. assistance mission and UNSC Resolutions, which a posteriori validated the occupation situation, as well as the rights and duties of occupying powers under the law of occupation. In this way, the Iraqi experience is found to be at a crossroads between occupation, international assistance mission, and affiliation with the U.N. Trusteeship System because the ground actor is a state but is looking for the remote support of an international institution (legitimacy and legality).

\footnotetext{
123 «Il s’agit d’un Etat souverain, dépourvu d'appareil étatique proprement dit, et qui est soumis à un régime d'occupation militaire et à une certaine règlementation internationale découlant de résolutions du Conseil de sécurité » [It is a sovereign state, devoid of state apparatus, and which is subjected to a military occupation regime and to a certain international regulation issued from UNSC resolutions]. Resolution 1511 creates the U.N. Assistance Mission for Iraq (UNAMI) to assist the SRSG established by Resolution 1483. Parcelo G. Kohen, L'administration actuelle de l'Irak: vers une nouvelle forme de protectorat?, in Karine Bannelier, Olivier Corten, Théodore Christakis \& Pierre Klein, L'INTERVENTION EN IRAK ET LE DROIT INTERNATIONAL 300 (2004); ELAINE L. HALCHIN, CONG. Research Serv., RL32370, The Coalition Provisional Authority (CPA): Origins, CHARACTERISTICS, AND INSTITUTIONAL AUTHORITIES (2005).

124 S.C. Res. 1483, U.N. Doc. S/RES/1483 (May 22, 2013); S.C. Res. 1511, U.N. Doc. S/RES/1511 (Oct. 16, 2003).

125 Adam Roberts, Transformative Military Occupation: Applying the Laws of War and Human Rights, 100 AM. J. INT'L. L. 580 (2006); Rüdiger Wolfrum, Iraq - from Belligerent Occupation to Iraqi Exercise of Sovereignty: Foreign Power versus International Community Interference, 9 MaX PlancK Y.B. OF United NATIONS L. 1, 16-20 (2005) (Ger.).

126 James Dobbins, Occupying Iraq: A Short History of the CPA, 51 SuRvivAL 131 (2009) (U.K.).
} 
Beyond this particular case, it is true that there are several difficulties inherent to IPBAs, despite their success in reading their mandate $\mathrm{BiH}$ is a state on the road to EU membership, and Kosovo and East Timor became independent states): the need for a strong political will in international society to use this mechanism for dispute and/or conflict resolution; the burdensharing over the long term, which means that the financial efforts must be maintained, even when the territory is no longer at the heart of the international agenda; the authoritarian approach and the problem of timing, as regards the transfer of responsibilities to local representatives, which can slow down state-building; the question of the IPBA's legality and legitimacy, and especially the limit to its authority, which refers to responsibility and accountability problems that the international actor meets in the field; ${ }^{127}$ the subjectivity of the appellation "temporary" in terms of duration; and the local perception (reformist trend or confrontation) or the clash between strategies bottom up and top down. Nevertheless, the worst pitfall, which explains the abandon of plenary IPBAs, is the exit strategy problem. Indeed, whether in $\mathrm{BiH}$, Kosovo, or East Timor, it has always been a problem. Almost fifteen years later, $\mathrm{OHR}$ in $\mathrm{BiH}$ is expecting its upcoming closure, as soon as the " 5 objectives and 2 conditions" are met, while at the same time, a strong European delegation with a Special Representative of the European Union (EUSR) should guide the independent BiH into Europe. ${ }^{128}$ In Kosovo, despite a structured and strict application of Resolution 1244, there are still monitoring problems, especially about the legitimacy/legality of EULEX under the U.N. umbrella and nothing had been prepared to close UNMIK, even if Kosovo is today an independent state. ${ }^{129}$ In East Timor, express statebuilding in less than three years has had serious consequences for the U.N. assistance missions that follow by virtue of the exit strategy adopted. ${ }^{130}$ These obstacles relate to the usual question in the international sphere "Who guards the guardians?”131

Thus, criticism against intrusive plenary forms updates an old idea. It is about preserving local capacity and the internal decision-making process: the ownership concept (by locals) makes perfect sense and takes ascendancy over considerations related to the viability of a state. ${ }^{132}$ This is the return of

\footnotetext{
127 Since the law of occupation applies only to states, an international organization cannot be affected by these principles. IPBA specialists emphasize the need to strengthen the responsibility of the international actor and its accountability. Mortimer, supra note 52, at 714.

128 InT’L CRISIS GRP, BOSNIA’s GORDIAN KNOT: CONSTITUTIONAL REFORM (2012).

${ }^{129}$ InT’L Crisis Grp, North Kosovo: Dual Sovereignty in Practice (2011).

130 INT'L CRISIS GRP, RESOLVING TIMOR-LESTE’s CRISIS (2006).

${ }^{131}$ Richard Caplan, Who Guards the Guardians? International Accountability in Bosnia, 12 INT'L PEACEKEEPING 463 (2005) (U.K.).

132 Org. Econ. Co-operation \& Dev., Development Partnership in the new Global ConTEXT (1995); Simon Chesterman, Ownership in Theory and Practice: Transfer of Authority UN Statebuilding Operation, 1 J. INTERVENTION \& STATEBUILDING 3 (2007) (U.K.).
} 
assistance missions. The general idea is to focus on the responsibility of local representatives so that they exercise direct control over the internal affairs of the territorial unit concerned since the imposition of constitutional liberalism by external actors harms the democracy-building process. ${ }^{133}$ The perfect illustration is the U.N. Assistance Mission in Afghanistan (UNAMA) introduced after the Bonn Agreement. In this case, the commitment of the United Nations is very limited, as desired by the representatives of various Afghan communities and interventionist powers. The structure of the mission is to support the local authority to resolve internal disputes. ${ }^{134}$ This model, which is strangely reminiscent of peace operations in the fifties (Libya and Eritrea), implements a "light approach" (light footprint). In this sense, the early twenty-first century is marked by a shift towards peace missions based exclusively on assistance as evidenced by the following experiments: United Nations Mission in Liberia (UNMIL), ${ }^{135}$ U.N. Mission for Stabilization in Haiti (MINUSTAH), ${ }^{136}$ United Nations Operation in Burundi (ONUB), ${ }^{137}$ United Nations Mission in the Democratic Republic of Congo (MONUC), ${ }^{138}$ the United Nations Operation in Côte d'Ivoire (UNOCI), ${ }^{139}$ as well as the political component of the U.N. Mission in South Sudan (UNMISS) where it is "to consolidate peace and security and help create conditions for the development of the Republic of South Sudan, the idea being to give the Government of the Republic of South Sudan means to govern the country effectively and democratically." 140

So, faced with criticism about authoritarianism, the United Nations prefers not to exercise a governmental function and is satisfied with an assistance role, insofar as the ownership strategy strengthens assistance missions in the doctrine. After the 2005 World Summit, by setting out the prerogatives of the U.N. Peacebuilding Commission and enhancing the concept of "responsibility to protect" (primarily by the states themselves), the UNSC and the UNGA stressed the importance of local ownership. ${ }^{141}$

\footnotetext{
133 James D. Fearon \& David D. Laitin, Neotrusteeship and the Problem of Weak States, 28 INT'L SECURITY 5 (2004).

${ }^{134}$ Agreement on Provisional Arrangements in Afghanistan Pending the Re-Establishment of Permanent Government Institutions, in letter dated 5 Dec. 2001 from the Secretary-General addressed to the President of the Security Council, U.N. Doc. S/2001/1154 (Dec. 5, 2001).

135 S.C. Res. 1509, ๆ 3, U.N. Doc. S/RES/1509 (Sept. 19, 2003).

136 S.C. Res. 1542, ๆ 7, U.N. Doc. S/RES/1542 (April 30, 2004).

${ }^{137}$ In January 2007, it was replaced by the U.N. Integrated Office in Burundi, which is in turn replaced by the United Nations Office in Burundi. S.C. Res. 1545, ๆף 6-7, U.N. Doc. S/RES/1545 (May 21, 2004); S.C. Res. 1959, ๆף 1-3, U.N. Doc. S/RES/1959 (Dec. 16, 2010). 138 S.C. Res. 1565, U.N. Doc. S/RES/1565 (Oct. 1, 2004); S.C. Res. 1925, paras. 1-3, U.N. Doc. S/RES/1925 (May 28, 2010).

139 S.C. Res. 1633, U.N. Doc. S/RES/1633 (Oct. 21, 2005).

140 S.C. Res. 1996, ๆ 3, U.N. Doc. S/RES/1996 (July 8, 2011).

141 The Peacebuilding Commission, G.A. Res. 60/180, pmbl., U.N. Doc. A/RES/60/180 (Dec. 30, 2005); 2005 World Summit Outcome, G.A. Res. 60/1, ๆף 138-39, U.N. Doc. A/RES/60/1
} 
Moreover, soft law documents produced in recent years by the UN Department of Peacekeeping Operations (DPKO), whether the Capstone doctrine, ${ }^{142}$ documents relating to the "New Horizon" peace operations approach, ${ }^{143}$ or the Civil Affairs Handbook, ${ }^{144}$ are in total agreement with this, that is to say in favour of local ownership and a simple assistance of the United Nations. This shift is due to pragmatic reasons: a peace operation with strong powers is impossible to implement due to geopolitical and geostrategic criteria, the opposition of local representatives to the interference in local affairs, sacred classical legal principles crowning the Westphalian state (territorial integrity, sovereignty and state equality), and local obstructionism. The strong opposition to international action is found especially in transition countries formerly colonized or occupied.

\section{CONCLUSION}

To conclude, the analysis of IPBAs has been put forward both as a category within the large family of territorial administration in international relations (colonial trusteeship, protectorate, occupation, LoN mandates and U.N. Trusteeship System) and as a specific concept close to peace operations which can itself be broken down into several models. An IPBA is the exercise of administrative authority by an international actor for the benefit of the population of the territory that is temporarily placed under control and/or supervision or under plenary or partial administration to achieve common goals in the form of an international public service. It is a political institution established to manage a dispute related to governance vacuum and/or territorial status of a special territory. Several elements serve to emphasize

(Oct. 24, 2005); S.C. Res. 1674, ๆ 4, U.N. Doc. S/RES/1674 (Apr. 28, 2006); S.C. Res. 1645, pmbl., U.N. Doc. S/RES/1645 (Dec. 20, 2005); U.N. Secretary-General, In Larger Freedom: Towards Development, Security and Human Rights for All: Rep. of the Secretary-General, $\mathbf{q 1}$ 16-22, U.N. Doc. A/59/2005 (Mar. 24, 2005); Rep. of the High-level Panel on Threats, Challenges \& Change, transmitted by letter dated 1 Dec. 2004 from the Chair of the Highlevel Panel on Threats, Challenges and Change addressed to the Secretary-General, A More Secure World: Our Shared Responsibility, I 201, U.N. Doc. A/59/565 (Dec. 2, 2004); INT’L COMM'N ON INTERVENTION \& STATE SOVEREIGNTY, THE RESPONSIBILITY TO PROTECT 17-19 (2001); Carsten Stahn, Responsibility to Protect: Political Rhetoric or Emerging Legal Norm?, 101 AM. J. INT'L L. 99, 100-118 (2007).

${ }^{142}$ See the three fundamental principles (consent, impartiality, and non-excessive use of force). U.N. DeP'T of PeaceKeeping Operations \& DeP'T of Field Support, U.N. Peacekeeping OPERATIONS: PRINCIPLES AND GUIDELINES (2008).

143 Department of PeacekeEping Operations and Department of Field Support, A New Partnership Agenda: Charting a New Horizon for UN Peacekeeping (2009); U.N. Secretary-General, Implementation of the Recommendations of the Special Committee on Peacekeeping Operations: Rep. of the Secretary-General, U.N. Doc. A/64/573 (Dec. 22, 2009).

144 U.N. Dep't of Peacekeeping Operations \& Dep’t of Field Support, Civil Affairs HANDBOOK (2012). 
the particularity of the model of IPBAs compared to peace operations or other forms of territorial administration such as the status of the territory (entity attached to a state or territorial unit of self-determination), the legality and/or the legitimacy (consent, treaty agreement, international mandate, etc.), the function of post-belligerency (internal, external. or mixed), and the temporary duration or the size of territory (geopolitical criterion). Although the particularism of IPBA's experiences is the axiomatic basis of the analysis due to its ad hoc nature, other criteria are used to outline a taxonomy while refining the definition of an IPBA. The specific causes for the establishment of an IPBA (problems of sovereignty and governance), the different policies implemented by international temporary political institutions, the degree of authority (partial, incremental and/or plenary), the local perception (Herodianism or Zealotism), and specificity of radical forms of IPBA in the post-Cold War promote the construction of a taxonomy. However, it is clear that this classification is non-exhaustive, as the consideration of all the criteria would result in the construction of a too heavy and unclear typology, even if the characteristics of post-Cold War plenary IPBAs, such as exceptionalism, multifunctionality, are highlighted in particular for the OHR, UNMIK, and UNTAET cases. Ultimately, although this analysis stresses the decline of IPBAs and underlines the return to the forefront of international assistance missions, it is too early to observe a guiding line in this change. This technocratic approach based on local capacity-building, partnership, and ownership badly masks political realities, where the Leviathan has collapsed. So, it would be elementary to predict a kind of calling into question of this type of mission in the next few years, in particular considering the failure in South Sudan.

In this new century, the difficulty regarding IPBAs is to find the right equilibrium between the authority of an international actor exercising executive, legislative, judicial, and administrative powers in a territory with local ownership. Indeed, it is necessary to be more vigilant to allow this kind mechanism of conflict resolution (a cure for sovereign problem and/or a remedy for governance vacuum) in order to begin a new cycle, taking into account the new standards of international law. This will inevitably involve a multilateral commitment in a long-term perspective. In this way, this type of project would fully enjoy success in the international order, which oscillates between the Westphalian system and a cosmopolitan world. This long-term multilateral commitment of the whole international society must ensure that, beyond the central issue of accountability, each IPBA truly respects the timing of each stage (plenary administration, partnership, and ownership), without minimizing the exit strategy planning, in particular in the form of an assistance mission. Without this awareness, there will be no IPBAs renewal in territorial administrations within international relations. 
